\title{
Transgenic Mice Expressing LHX3 Transcription Factor Isoforms in the Pituitary: Effects on the Gonadotrope Axis and Sex-Specific Reproductive Disease
}

JESSE J. SAVAGE, ${ }^{1,2}$ RACHEL D. MULLEN, ${ }^{\prime}$ KYLE W. SLOOP, ${ }^{3}$ STEPHANIE C. COLVIN, ${ }^{1,2}$ SALLY A. CAMPER, ${ }^{4}$ CRAIG L. FRANKLIN, ${ }^{5}$ AND SIMON J. RHODES ${ }^{\prime *}$

'Department of Cellular and Integrative Physiology, Indiana University School of Medicine, Indianapolis, Indiana

${ }^{2}$ Department of Biology, Indiana University-Purdue University Indianapolis, Indianapolis, Indiana

${ }^{3}$ Endocrine Discovery, Lilly Research Laboratories, Eli Lilly and Company, Indianapolis, Indiana

${ }^{4}$ Department of Human Genetics, University of Michigan, Ann Arbor, Michigan

${ }^{5}$ Research Animal Diagnostic Laboratory, Department of Veterinary Pathobiology,

University of Missouri-Columbia, Columbia, Missouri

The LHX3 transcription factor plays critical roles in pituitary and nervous system development. Mutations in the human $L H X 3$ gene cause severe hormone deficiency diseases. The gene produces two mRNAs which can be translated to three protein isoforms. The LHX3a protein contains a central region with LIM domains and a homeodomain, and a carboxyl terminus with the major transactivation domain. LHX3b is identical to LHX3a except that it has a different amino terminus. M2-LHX3 lacks the amino terminus and LIM domains of LHX3a/ b. In vitro experiments have demonstrated these three proteins have different biochemical and gene regulatory properties. Here, to investigate the effects of overexpression of LHX3 in vivo, the alpha glycoprotein subunit ( $\alpha G S U)$ promoter was used to produce LHX3a, LHX3b, and M2-LHX3 in the pituitary glands of transgenic mice. Alpha GSU-beta galactosidase animals were generated as controls. Male $\alpha G S U-L H X 3 a$ and $\alpha$ GSU-LHX3b mice are infertile and die at a young age as a result of complications associated with obstructive uropathy including uremia. These animals have a reduced number of pituitary gonadotrope cells, low circulating gonadotropins, and possible sex hormone imbalance. Female $\alpha$ GSU-LHX3 $a$ and $\alpha$ GSU-LHX3b transgenic mice are viable but have reduced fertility. By contrast, $\alpha$ GSUM2-LHX3 mice and control mice expressing beta galactosidase are reproductively unaffected. These overexpression studies provide insights into the properties of $\mathrm{LHX} 3$ during pituitary development and highlight the importance of this factor in reproductive physiology.

J. Cell. Physiol. 212: 105-I 17, 2007. (C) 2007 Wiley-Liss, Inc.

The mammalian anterior pituitary gland releases hormones that regulate many aspects of development and physiology, including reproduction, growth, the response to stress, metabolism, and lactation. In the mature gland, specialized cells produce and secrete these hormones; for example, the gonadotrope cell synthesizes luteinizing hormone (LH) and folliclestimulating hormone $(\mathrm{FSH})$ and the thyrotrope makes thyroidstimulating hormone (TSH). The regulatory signals that coordinate the determination, expansion, and differentiation of hormone-secreting cells from the progenitors that populate Rathke's pouch, the pituitary primordium, are only partially characterized. It is known that following early inductive events between Rathke's pouch and the neural ectoderm of the ventral diencephalon, the actions of several classes of transcription factors orchestrate the establishment of the hormonesecreting cell types of the anterior lobe (Keegan and Camper, 2003; Savage et al., 2003; Zhu and Rosenfeld, 2004). These transcription factors include EGR I, HESX I, ISL I, LHX3, LHX4, PAX6, PITI, PITXI, PITX2, PROPI, SFI, SIX3, SIX6, and TPIT. LHX3, LHX4, and ISLI are members of the LIM-homeodomain (LIM-HD) family of transcription factors that includes many key regulators of mammalian organogenesis (Hunter and Rhodes, 2005). LIM-HD proteins are classified by the presence of two cysteine-rich finger-like structures, the LIM domains, and a characteristic DNA-binding homeodomain. The LIM motif has been shown to participate in the gene regulatory functions of LIM-HD proteins by modulation of DNA binding affinity and mediation of interactions with ubiquitous and tissue-restricted protein partners (Bach, 2000; Hobert and Westphal, 2000; Hunter and Rhodes, 2005).

Much of what is understood about pituitary developmental biology originates from studies involving the characterization of loss of function and overexpression mouse models and the

Contract grant sponsor: National Institutes of Health; Contract grant numbers: HD42024, K26 RRO188II, HD34283. Contract grant sponsor: National Science Foundation. Contract grant number: IBN 0131702 .

*Correspondence to: Simon J. Rhodes, Department of Cellular and Integrative Physiology, Indiana University School of Medicine, Med Sci Room 362A, 635 N. Barnhill Drive, Indianapolis, IN 46202-5I 20. E-mail: srhodes@iupui.edu

Received 31 October 2006; Accepted 5 December 2006

DOI: $10.1002 /$ jcp.21010 
analysis of human patients with hormone deficiency disorders. In mammals, LHX3 mRNAs are detected in the embryonic nervous system and in both the developing and established anterior/intermediate lobes of the pituitary (Seidah et al., 1994; Bach et al., 1995; Zhadanov et al., 1995). The phenotype of mice with a homozygous deletion of the entire $L h \times 3$ gene reflects the importance of this transcription factor in pituitary and nervous system development (Sheng et al., 1996, 1997; Sharma et al., 1998). These animals are not viable after birth, and morphological and molecular analyses demonstrate that they have incomplete pituitary development and aberrant motor neuron differentiation (Sheng et al., 1996, 1997; Sharma et al., 1998). The partially developed pituitary of $L h \times 3$ null mice retains some adrenocorticotropin (ACTH)-expressing corticotrope cells, but other anterior pituitary hormones are not detected, consistent with a required role for LHX3 in gonadotrope, lactotrope, somatotrope, and thyrotrope cell differentiation (Sheng et al., 1996). Molecular and cellular in vitro studies have shown that $\mathrm{LHX} 3$ can bind to regulatory elements in the promoters or enhancers of anterior pituitary-expressed genes, including the $F S H \beta, \alpha G S U$, prolactin (PRL), TSH $\beta$, gonadotropin releasing hormone receptor, and Pit-I/POUIFI genes (e.g., Roberson et al., 1994; Bach et al., 1995; Sloop et al., 1999 , 200 la; Pincas et al., 200 I; West et al., 2004; McGillivray et al., 2005; Granger et al., 2006).

Loss of $L H X 3$ gene function in human patients causes severe hormone deficiency diseases. Patients with these recessive mutations have low or absent $\mathrm{LH}, \mathrm{FSH}, \mathrm{TSH}$, growth hormone $(\mathrm{GH})$, and PRL, with associated short stature, thyroid deficiency, and reproductive disease (Netchine et al., 2000; Bhangoo et al., 2006). In addition, these patients exhibit a rigid cervical spine leading to limited head rotation that likely results from abnormal motor neuron development. In humans and mice, loss of one LHX3 allele does not appear to have deleterious effects (Sheng et al., 1996; Netchine et al., 2000; Bhangoo et al., 2006).

Mammalian LHX3 genes produce two major mRNAs known as LHX3a and LHX3b (Zhadanov et al., 1995; Sloop et al., 1999, $200 \mathrm{Ia}$; Yaden et al., 2006). The mouse $L H X 3 a$ and $L H X 3 b$ mRNAs have distinct temporal expression profiles during development and are differentially expressed in rodent cell lines that represent various anterior pituitary cell types (Zhadanov et al., 1995; Sloop et al., 1999, 200 la; West et al., 2004). Translation from the first methionine codons of the $L H X 3 a$ and LHX3b mRNAs generates the LHX $3 a$ and $L H X 3 b$ protein isoforms, respectively (Zhadanov et al., 1995; Sloop et al., 1999). These proteins are identical for most of their amino acid sequences (LIM domains, homeodomain, and carboxyl terminus) but differ in their distinct amino termini resulting from alternate use of $5^{\prime}$ exons in the gene (Zhadanov et al., 1995; Sloop et al., 1999, 2000). A third protein isoform, $\mathrm{M} 2-\mathrm{LHX} 3$, is generated via translation of the second in-frame methionine (M2) codon of the LHX3a mRNA (Sloop et al., $200 \mathrm{la}$ ). M2-LHX3 lacks the amino terminus and LIM domains found in LHX3a and LHX3b (Sloop et al., 200la). The three LHX3 protein isoforms display different biochemical and functional properties (Sloop et al., 1999, 200 la,b; Yaden et al., 2005). The $\mathrm{LHX3a}$ isoform transactivates pituitary gene promoters, such as those of $F S H \beta, \alpha G S U$, and $T S H \beta$, more effectively than the LHX3b isoform (Sloop et al., 1999, 200 la; West et al., 2004). The differences in gene activation properties between $\mathrm{LHX} 3 \mathrm{a}$ and $\mathrm{LHX} 3 \mathrm{~b}$ reflect distinct DNA binding affinities; the LHX3b amino terminus is a specific inhibitor of homeodomain DNA binding and therefore gene activation (Sloop et al., 200la). In vitro experiments suggest that the LHX3b amino terminus impacts the DNA binding affinity of the LHX3 homeodomain but not its specificity; both LHX3a and LHX3b recognize similar optimal DNA binding sites (Bridwell et al., 200I; Yaden et al., 2005). The M2-LHX3 isoform has unique biochemical and gene regulatory properties. Because it lacks the amino terminus and LIM domains but retains the major activation domain of $\mathrm{LHX} 3$ (located in the carboxyl terminus of the molecule), M2-LHX3 binds target DNA sequences more avidly than the LHX3a and LHX3b isoforms and it can induce transcription from the PRL, $\alpha$ GSU, and TSH $\beta$ promoters more robustly than LHX3b (Sloop et al., 200 la).

Observations of loss of $L H X 3$ gene function (the $L h \times 3$ knockout mouse model and the discovery of human patients with $L H X 3$ mutations) have demonstrated the requirement for $\mathrm{LHX} 3$ during pituitary development. However, little is known of the regulatory roles of $\mathrm{LHX} 3$ protein isoforms in vivo. To investigate the effects of $\mathrm{LHX} 3$ targeted expression in vivo, we generated strains of transgenic mice overexpressing each of the three LHX3 isoforms during pituitary development. Transgenic mice expressing specific LHX3 proteins display a sex-specific reduction in viability and develop reproductive diseases associated with hormonal dysregulation. This study provides insights into the sensitivity of the pituitary to LHX3 dosage and has generated transgenic mice that will serve as models for male reproductive diseases.

Materials and Methods

Experimental animals

All animal experimentation described in this study was conducted in accord with accepted standards of humane animal care, the NIH guidelines for the care and use of experimental animals, and protocols approved by the institutional animal care and use committees of the Indiana University School of Medicine, the Purdue University School of Science Indianapolis, and the University of Missouri.

\section{Cell culture and transfection assays}

Mouse pituitary GHFTI -5 cells (a gift from Dr. P. Mellon, University of California San Diego) were cultured and transfected as described (Sloop et al., 200la)

\section{Transgene construction}

Transgene design is shown in Figure IA. The $\alpha$ GSU-nLacZ transgene plasmid has been described (Kendall et al., 1994). In addition to $-4.6 \mathrm{~kb}$ of the mouse $\alpha G S U$ promoter, this vector contains the Escherichia coli lacZ gene fused to the SV40 T antigen nuclear localization signal and a portion of the murine protamine- $I$ gene that provides $3^{\prime}$-UTR, intronic, and polyadenylation signal sequences. To generate the $\alpha G S U-L H X 3 a$, $\alpha G S U-L H X 3 b$, and $\alpha G S U-M 2-L H X 3$ transgenes, LHX3 coding sequences were amplified by the PCR from existing $L H X 3$ expression vectors using Pfu DNA polymerase (Stratagene, La Jolla, CA) and the following primers: $5^{\prime}$-cgggatccaccatgctgctggaaacggggct- $3^{\prime}, 5^{\prime}$-cgggatcctcaattcagatcctcttctgagatgagtttttgttcgaactgagcgtggtctacctcatc- $3^{\prime}$ $\left(\right.$ LHX3a); 5' -cgggatccaccatggaggcgcgcggggagct- $3^{\prime}, 5^{\prime}$-cgggatcctcaattcagatcctcttctgagatgagtttttgttcgaactgagcgtggtctacctcatc- $3^{\prime}$ (LHX3b); and $5^{\prime}$ cgggatccaccatggaggacagccggctcgtg- $3^{\prime}, 5^{\prime}$-cgggatcctcaattcagatcctcttctgagatgagtttttgttcgaactgagcgtggtctacctcatc- $3^{\prime}(M 2-L H X 3)$. The substrates for LHX3a and LHX3b transgenes were full-length cDNAs in which the second methionine (M2) had been replaced with alanine by sitedirected mutagenesis (Sloop et al., 200 la) to prevent production of M2-LHX3. The PCR products were inserted into a BamHI site downstream of the $\alpha$ GSU promoter cloned in pGEM7Zf + (Kendall et al., 1994) that had been partially BamHI digested and calf intestinal alkaline phosphatase treated. Transgene integrity was confirmed using a Perkin Elmer DNA sequencer (Biochemistry Biotechnology Facility, Indiana University School of Medicine). Sequence analyses and assembly were performed using DNASIS (Hitachi Software Engineering, South San Francisco, CA) software.

\section{Generation of transgenic mice}

The $\alpha$ GSU-nLacZ, $\alpha$ GSU-LHX3a, $\alpha$ GSU-LHX3b, and $\alpha$ GSU-M2-LHX3 plasmids were linearized by digestion with $\mathrm{Kpnl} / \mathrm{Hind}$ lll. The linearized fragments were microinjected into $\mathrm{F} 2$ zygotes from $(\mathrm{C} 57 \mathrm{BL} / 6 \mathrm{~J} \times \mathrm{CBA})$ FI parents (Purdue University Transgenic Mouse Core Facility, West Lafayette, IN). Embryos at the two-cell stage were transferred to 0.5 -day post-coitum pseudopregnant CD-I females. Genomic DNA 
A
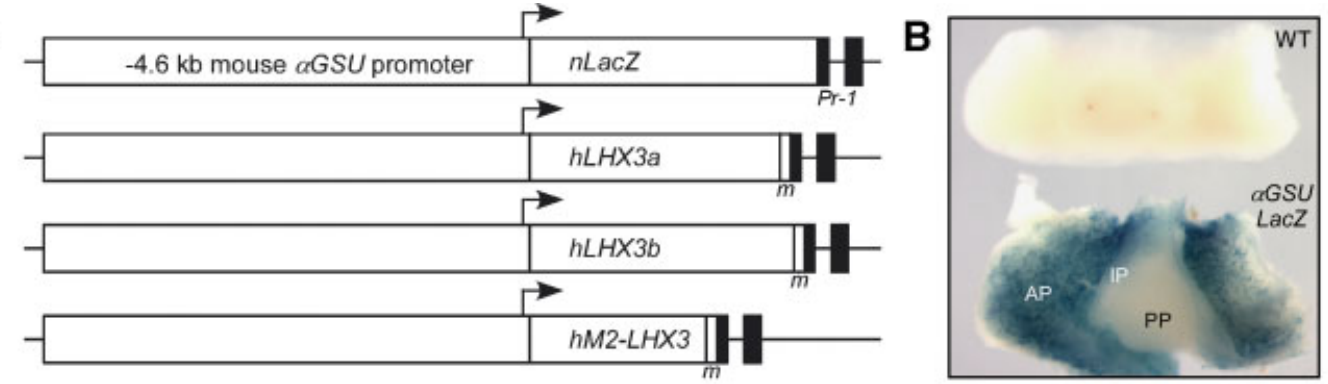

C

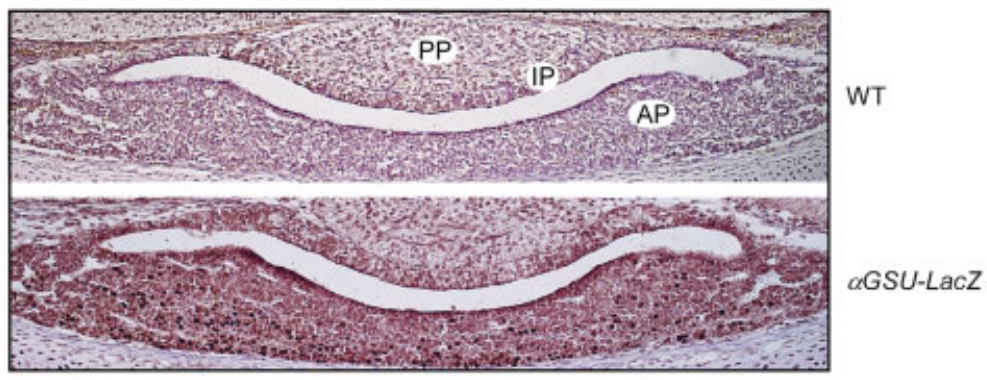

D

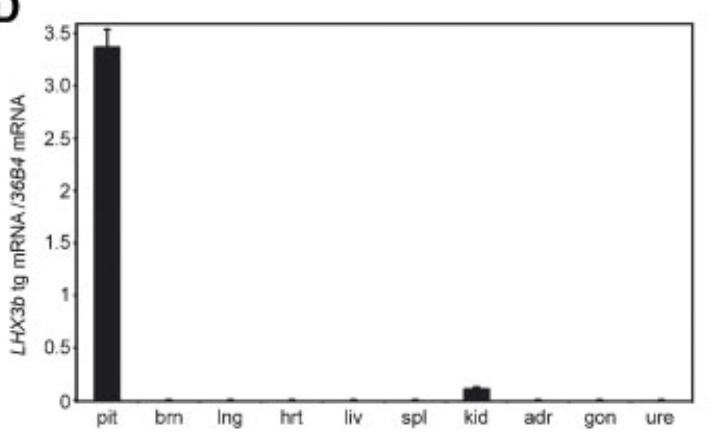

E

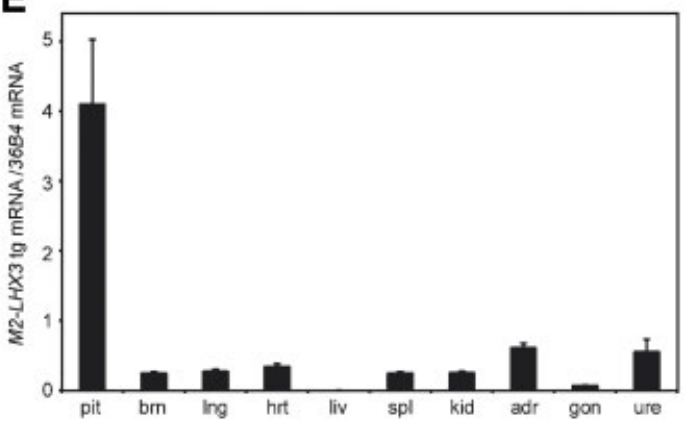

$\mathbf{F}$

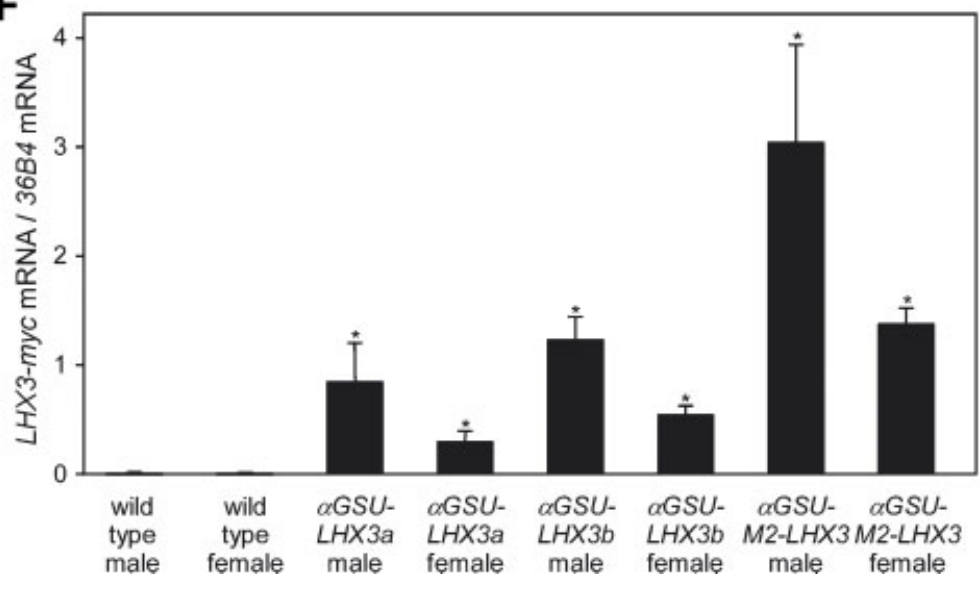

Fig. I. Transgenic mice expressing LHX3 isoforms. A: $\alpha$ GSU-nLacZ and $\alpha G S U-L H X 3$ transgenes. Complementary DNAs encoding $n L a c Z$, human LHX3a, LHX3b, or M2-LHX3 were placed under the control of $4.6 \mathrm{~kb}$ of the mouse $\alpha G S U$ promoter. The LHX3 cDNAs were tagged with a Myc-epitope $(\mathrm{m})$ and followed by a mouse protamine intron and poly(A) signal $(\mathrm{Pr}-\mathrm{I})$. B: The $\alpha G S U-n L a c Z$ transgene is expressed at high levels within the anterior pituitary lobe. Whole mount wild-type (WT) and transgenic ( $\alpha$ GSU-nLacZ) pituitaries stained for $\beta$-galactosidase activity at $\mathbf{2}$ weeks of age. PP = posterior pituitary; IP = intermediate pituitary; AP = anterior pituitary. C: Detection of transgene expression

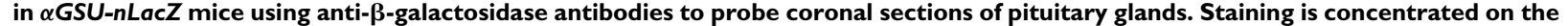
ventral side of the gland. D,E: Expression of transgene mRNA in tissues. Using quantitative real-time PCR, male transgenic mice were assayed at I 2 weeks of age for expression of transgene product. Results are the means of three assays \pm SEM. After RNA extraction from pituitary tissue, cDNAs were generated using oligo d(T), and PCR was performed using transgene-specific primers. Reactions were monitored in real time using internal fluorescent transgene-specific TaqMan probes. Calculated RNA levels were normalized to measurements of the acidic ribosomal phosphoprotein PO (ARBP/36B4) mRNA levels performed in parallel control reactions. Pit $=$ pituitary, brn = brain, Ing $=$ lung, liv = liver, spl = spleen, $\mathbf{k i d}=$ kidney, adr = adrenal, gon = gonad, ure = urethra. F: Genotype and sex-specific variation of $\alpha$ GSU-LHX3 transgene expression in the pituitary assayed by quantitative real-time PCR in I 2-week-old mice. ${ }^{*} P<0.000$ I versus control. [Color figure can be viewed in the online issue, which is available at www.interscience.wiley.com.] 
prepared from tail biopsies of weanlings was screened for the presence of the transgene and a control amplicon by the PCR using the following primers: $5^{\prime}$-aggactgggtggcttccaactcccagacac- $3^{\prime}, 5^{\prime}$-agcttctcattgctgcgcgcc-aggttcagg- $3^{\prime}$ (positive control, Rapsn [acetylcholine receptor] gene); $5^{\prime}$-ttcactggccgtcgttttacaacgtcgtga- $3^{\prime}, 5^{\prime}$-atgtgagcgagtaacaacccgtcggattct-3' ( $\alpha$ GSU-nLacZ); 5' -tgtgtaagggtcaataatattaca- $3^{\prime}, 5^{\prime}$-gtgccagtggcggtccagagcctt- $3^{\prime}(\alpha G S U-L H X 3 a$ and $\alpha G S U-L H X 3 b)$; and $5^{\prime}$-tgtgtaagggtcaataatattaca- $3^{\prime}, 5^{\prime}$-gcgcgccggcttgggcgaggtgtt-3' $(\alpha$ GSU-M2-LHX3). Transgenic founder animals and their progeny were crossed to $\mathrm{C} 57 \mathrm{BL} / 6 \mathrm{~J}$ mice (The Jackson Laboratory, Bar Harbor, ME). Transgenes were maintained in a hemizygous state. Mice were housed in a specific pathogen-free environment under controlled conditions of temperature and light and provided with tap water and commercial mouse chow. Wild-type and transgenic mice used in fertility studies were housed as single breeding pairs for at least 4 months for fertility and fecundity tests. Comparative data for wild-type male and female reproductive performance were obtained from The Jackson Laboratory database. The frequency of birth, number of offspring, and genotype were recorded. Vaginal plugs were monitored each morning to confirm copulation.

\section{RNA extraction and cDNA synthesis}

Tissues harvested during necropsy were homogenized directly in TriReagent (Molecular Research Center, Cincinnati, $\mathrm{OH}$ ) and frozen in liquid nitrogen. RNA was isolated using the Tri-Reagent extraction protocol with the following changes: bromochloropropane was used as a chloroform substitute, and prior to RNA precipitation, $2.0 \mathrm{U}$ of RNase-free DNase I (Ambion, Austin, TX) were added to each sample and placed at $37^{\circ} \mathrm{C}$ for $30 \mathrm{~min}$. The RNA/DNase I mixture was backextracted with Tri-Reagent to purify DNA-free RNA. Complementary DNA was synthesized using Superscript II reverse transcriptase and an oligo d(T) primer (Invitrogen, Carlsbad, CA).

\section{Quantitative PCR analyses of gene expression}

Reverse transcriptase (RT) reactions were performed in duplicate as described above using oligo $\mathrm{d}(\mathrm{T})$ primer and total RNA. Parallel negative control reactions omitted the RT. Real-time quantitative PCR was performed using the $5^{\prime}$ fluorogenic nuclease assay and an ABI 7900 PRISM (Applied Biosystems, Foster City, CA). The $5^{\prime}$ terminus of fluorogenic probes was labeled with 6-carboxy-fluorescein, and the $3^{\prime}$ terminus contained the quenching dye 6-carboxytetramethylrhodamine. Positive control reactions amplified the 36B4 cDNA (encoding the acidic ribosomal phosphoprotein P0) as described (West et al., 2004). Negative control reactions were performed lacking RT. The $\alpha$ GSU, LHX3-Myc, and 36B4 primers and probes were synthesized by Biosearch Technologies (Novato, CA). Primer and probe sequences were as follows: $\alpha$ GSU forward primer, $5^{\prime}$-ctgttgcttctccagggcata- $3^{\prime}, \alpha G S U$ reverse primer, $5^{\prime}$ ttctttggaaccagcattgtctt- $3^{\prime}, \alpha$ GSU TaqMan probe, $5^{\prime}$-cccactcccgccaggtccaa-3'; LHX3-Myc forward primer, 5' -ggtagaccacgctcagttcga- $3^{\prime}$, LHX3Myc reverse primer, $5^{\prime}$-cggcatctgctcctgctt- $3^{\prime}$, LHX3-Myc TaqMan probe, $5^{\prime}$-agaagaggatctgaattgaggatccgcag- $3^{\prime} ; 36 B 4$ forward primer, $5^{\prime}$-ggcccgagaagacctcctt- $3^{\prime}, 36 \mathrm{~B} 4$ reverse primer, $5^{\prime}$-tcaatggtgcctctggagatt$3^{\prime}, 36 B 4$ TaqMan probe, $5^{\prime}$-ccaggctttgggcatcaccacg- $3^{\prime}$. Amplifications were run in triplicate $20 \mu \mathrm{l}$ reactions that contained Universal Master Mix (Applied Biosystems), 4 pmol of each forward and reverse primer, 3 pmol probe, and $4 \mu$ l diluted cDNA from the RT reactions. Two-step PCR cycling was carried out as follows: $50^{\circ} \mathrm{C} 2 \mathrm{~min}$ for one cycle, $95^{\circ} \mathrm{C}$ $10 \mathrm{~min}$ for one cycle, and $95^{\circ} \mathrm{C} I 5 \mathrm{sec}$ and $60^{\circ} \mathrm{C} \mathrm{I}$ min for 40 cycles. Data were normalized by determining the relative abundance of $36 \mathrm{~B} 4$ mRNA.

\section{Histology and immunohistochemistry}

Harvested tissues were fixed in $4 \%$ paraformaldehyde in PBS ( $\mathrm{pH} 7.2$ ) at $4^{\circ} \mathrm{C}$ for 2-24 h. The fixed samples were washed in PBS, dehydrated, and embedded in paraffin. Tissue sections of $6 \mu \mathrm{m}$ were prepared for subsequent hematoxylin/eosin staining or immunohistochemical analyses. Tissue sections were deparaffinized, rehydrated, and antigen unmasked ( 10 min boil in $10 \mathrm{mM}$ citric acid [pH 6.0]) prior to immunostaining. Immunohistochemistry was performed with polyclonal antisera against $E$. coli $\beta$-galactosidase $(I: 2,000)$ (Chemicon, Temecula, CA), human ACTH ( $1: 1,000$ for diaminobenzidine [DAB, Sigma, St. Louis, MO] chromogen staining) (AFP-39032082), rat $\alpha$ GSU (I:500 DAB) or (I:100 fluorescence [Fluor]) (AFP-66P9986), rat GH (I:I,000 DAB) (AFP-5672099), rat LH $\beta$ (I:800 DAB) or ( I:400 Fluor)
(AFP-57 I292393), rat TSH $\beta$ (I:I,000 DAB) or (I:500 Fluor) (AFP-I 274789) (National Hormone and Pituitary Program [NHPP], Torrance, CA), human c-Myc (I:200 DAB) or (I:50 Fluor) (Santa Cruz Biotechnology, Santa Cruz, CA), mouse LIM-3/LHX3 (I:I,000 DAB) (Chemicon) and mouse LIM-3/LHX3 (I:I,000 DAB) (Developmental Studies Hybridoma Bank at the University of lowa under the auspices of the National Institute of Child Health \& Human Development). Biotinylated secondary antibodies were used with avidin and biotinylated peroxidase or fluorescent avidin alone (Vectastain rabbit and M.O.M. kits; Vector Laboratories, Burlingame, CA). Normal serum was substituted for primary antibody in parallel negative control experiments. Selected slides were hematoxylin and eosin counterstained in order to examine tissue morphology. Whole mount pituitaries to be assayed for $\beta$-galactosidase activity were fixed for $10 \mathrm{~min}$ in $0.2 \%$ glutaraldehyde, washed three times in detergent rinse (0.I $\mathrm{M} \mathrm{NaH}_{2} \mathrm{PO}_{4}[\mathrm{pH} 7.3], 2 \mathrm{mM} \mathrm{MgCl} 2,0.2 \% \mathrm{NP}-40$ ), and incubated at $37^{\circ} \mathrm{C}$ overnight in an X-Gal solution containing I mg/ $\mathrm{ml} \mathrm{X-Gal} \mathrm{(Roche} \mathrm{Applied} \mathrm{Science,} \mathrm{Indianapolis,} \mathrm{IN),} 5 \mathrm{mM} \mathrm{K}_{3} \mathrm{Fe}(\mathrm{CN})_{6}$, and $5 \mathrm{mM} \mathrm{K}{ }_{4} \mathrm{Fe}(\mathrm{CN})_{6} \cdot 3 \mathrm{H}_{2} \mathrm{O}$ in detergent rinse.

\section{Microscopy}

Light and epifluorescence images were acquired with a Nikon Eclipse TE 200-U inverted microscope equipped with DAPI, FITC, TRITC, and Cy5 epifluorescence filter cubes or a Nikon Eclipse E400 microscope with an Olympus DP70 camera.

\section{Magnetic resonance imaging (MRI)}

A Varian 9.4 Tesla, $31 \mathrm{~cm}$ horizontal bore MR system (Varian, Inc., Palo Alto, CA; Department of Radiology, Indiana University School of Medicine) was used to image mouse urogenital anatomy. Mice were euthanized and imaged using a small $30 \mathrm{~mm}$ dual tuned $\left({ }^{1} \mathrm{H}\right)$ volume coil. Proton density spin echo images were obtained in the transverse and sagittal imaging planes. Repetition time $=1 \mathrm{sec}$, echo time $=12 \mathrm{msec}$, number of signal averages $=\mathrm{I}$, imaging time $=4 \mathrm{~min} 19 \mathrm{sec}$, slice thickness $=0.5 \mathrm{~mm}$, in-plane resolution $=137 \times 148$ microns.

\section{Hormone and blood chemistry analyses}

For sera collection, group housed mice were euthanized in the morning and whole blood was harvested via cardiac puncture; serum then was isolated and stored at $-20^{\circ} \mathrm{C}$. $\mathrm{LH}, \mathrm{FSH}$, testosterone, and estradiol levels were measured by the University of Virginia Center for Research in Reproduction Ligand Assay and Analysis Core. LH was measured in serum by a modified super-sensitive two-site sandwich immunoassay using monoclonal antibodies MABI (\#58IB7) against bovine $\mathrm{LH}$ and TMA (\#5303; Medix, Kauniainen, Finland) against the human LH $\beta$ subunit. The tracer antibody (\#5|8B7, kindly provided by Dr. Janet Roser, Department of Animal Science, University of California, Davis) was iodinated by the chloramine T method and purified on Sephadex G-50 columns. The capture antibody (\#5303) was biotinylated and immobilized on avidin-coated polystyrene beads $(7 \mathrm{~mm}$; Nichols Institute, San Juan Capistrano, CA). Mouse LH reference preparation provided by Dr. A. F. Parlow (NHPP) was used as standard. The assay has a sensitivity of $0.07 \mathrm{ng} / \mathrm{ml}$, and the average intra-assay and interassay coefficients of variation for the quality controls were $3.6 \%$ and I I. I\%, respectively. Mouse FSH levels were determined by RIA using reagents provided by Dr. Parlow. Mouse FSH reference preparation was used for assay standards, and mouse FSH antiserum (guinea pig) AFP- 1760191 , diluted to a final concentration of $1: 400,000$, was used as a primary antibody. Secondary antibody was purchased from Antibodies, Inc., Davis, CA (catalog \#5 I-534) and was diluted to a final concentration of I:60. The assay has a sensitivity of $2.0 \mathrm{ng} / \mathrm{ml}$ and less than $0.5 \%$ cross-reactivity with other pituitary hormones. The intra-assay and inter-assay coefficients of variation were $10.1 \%$ and $13.3 \%$, respectively. Testosterone levels were measured by solid-phase 125 I RIA using the Diagnostic Products Corporation (Los Angeles, CA) Coat-A-Count Total Testosterone Kit according to the manufacturer's instructions. Serum estradiol levels were assessed using the Diagnostic Systems Laboratories (Webster, TX) estradiol RIA Kit (DSL-4400) according to the manufacturer's instructions. Blood urea nitrogen (BUN) assays were performed by the University of Missouri Veterinary Medical Diagnostic Laboratory (Columbia, MO) using the Olympus Urea Nitrogen Kit in tandem with an Olympus AU400 analyzer (OSR6134, Olympus, Melville, NY) according to the manufacturer's instructions. 


\section{Statistical analysis}

Data points were compared using a one-tailed Student's t-test for paired samples using Excel (Microsoft Corp., Redmond, WA). Values were considered significantly different when $P<0.01$.

\section{Results}

\section{Generation of $\alpha$ GSU-LHX3 transgenic mice}

In order to characterize the in vivo consequences of persistent overexpression of $\mathrm{LHX} 3$, we generated transgenic mice expressing human $\mathrm{LHX} 3 \mathrm{a}$, LHX3b, or M2-LHX3 during pituitary development. The $-4.6 \mathrm{~kb}$ mouse $\alpha G S U$ promoter, a well-characterized promoter transcribed starting at embryonic day 9.5 throughout the pituitary primordium and later in thyrotrope and gonadotrope cell types (Kendall et al., 1994), therefore was chosen for these experiments. Prior to transgene construction the $\mathrm{M} 2$ methionine codon (which has the potential to produce the M2-LHX3 isoform) of the human $L H X 3 a$ and $L H X 3 b$ cDNAs was replaced with alanine to ensure uniform production of discrete $\mathrm{LHX} 3$ isoforms. Expression constructs containing the modified $L H X 3 a(M I 34 A)$ and $L H X 3 b$ (MI39A) cDNAs were assayed for their transactivation capacities using pituitary promoter luciferase reporter genes. The modified cDNAs had the same transcriptional capacities as wild-type controls (data not shown). The Myc epitope-tagged LHX3 cDNAs were then cloned under the control of the mouse $\alpha$ GSU promoter (Fig. IA), and these fragments were used to generate transgenic mice. AlphaGSU-nLacZ (beta galactosidase) mice were also generated to serve as comparative negative controls. Semi-quantitative RT-PCR of pituitary RNA was used to assay transgene expression within the $\alpha$ GSU-LHX3a, $\alpha$ GSU-LHX3b, $\alpha$ GSU-M2-LHX3, and $\alpha$ GSU$n L a c Z$ founder pedigrees. Approximately $50 \%$ of the transgenic lines expressed the transgene. No male transgene-expressing $\alpha G S U-L H X 3 a$ or $\alpha$ GSU-LHX3b founder mice survived. Six lines expressing the $\alpha G S U-M 2-L H X 3$ transgene and three lines expressing the $\alpha G S U-n L a c Z$ transgene were generated and bred for further study. By breeding through the females, one $\alpha G S U$ $L H X 3 a$ and two $\alpha G S U-L H X 3 b$ expressing lines survived. The three $\alpha G S U-L H X 3 a / b$ pedigrees developed the same disease phenotype (see below); the $\alpha$ GSU-M2-LHX3 and $\alpha$ GSU-nLacZ transgenic mice did not display any significant problems. Subsequently, representative lines demonstrating the highest levels of each transgene expression were used in the described experiments.

\section{aGSU-LHX3 transgene expression}

By whole mount $X-G a l$ substrate staining of pituitary glands and immunohistochemistry of pituitary sections using anti-Lac $Z$ antibodies, the $\alpha$ GSU-nLacZ transgenic control mice were found to exhibit appropriate LacZ expression within the anterior lobe of the gland, demonstrating the expected behavior of the promoter (Fig. IB,C). Real-time PCR was used to quantitatively evaluate the specific level of $L H X 3$ transgene expression in various tissues. The pituitary was the principal site of transgene production in all three pedigrees, but minor levels of transgene transcripts, but not protein, were detected in some other tissues (Fig. ID,E; and data not shown). Quantitative assays of LHX3 transgene transcripts within adult pituitaries revealed differences in expression levels across genotypes (Fig. IF). The $\alpha$ GSU-M2-LHX3 animals had the highest level of transgene expression, and the $\alpha G S U-L H X 3 b$ transgenics had a higher level of expression than $\alpha G S U-L H X 3 a$ mice. Interestingly, there were also sex-specific differences in transcript abundance with males maintaining a higher level of transgene expression than females. Real-time PCR experiments examining the endogenous $\alpha$ GSU gene were consistent with this observation, demonstrating that male mice exhibit higher expression levels than female mice (data not shown).

Specific detection of the $L H X 3$ transgene products using antiMyc antibodies showed expression in the anterior pituitary of the $\alpha$ GSU-LHX3a, $\alpha$ GSU-LHX3b, and $\alpha$ GSU-M2-LHX3

transgenic mice with strong detection in the nuclei of cells on the ventral side of the lobe, consistent with targeting the gonadotrope and thyrotrope cell types, compared to negative controls (Fig. 2A-D). Confirming the quantitative PCR data of mRNA transcript levels, the anti-Myc immunostaining showed there were similar differences in the levels of transgene protein expression with $\alpha$ GSU-M2-LHX3 $>\alpha G S U-L H X 3 b>\alpha G S U-$ LHX3a levels (Fig. 2B-D). Transgenic overexpression of LHX3 isoforms does not appear to significantly affect the abundance of endogenous LHX3. Immunohistochemical staining experiments using two different anti-LHX3 antibodies were consistent with these observations (data not shown). Transgenic mice expressing LHX3 isoforms demonstrated no notable alterations in overall pituitary morphology in comparison to wild-type littermates (Fig. 2A-D).

Immunostaining assays of other tissues such as the reproductive tract did not detect LHX3 protein in non-pituitary tissues (data not shown)

To confirm the cellular specificity of transgene expression, double-label immunohistochemistry was performed using fluorescently labelled antibodies to detect transgene-derived LHX3 protein and $\alpha$ GSU hormone expression. Control pituitary glands derived from wild-type littermates displayed no appreciable background immunofluorescence for the $L H X 3$ transgenes and maintained the expected $\alpha$ GSU expression patterns (Fig. 2E,I). Again, the differences in levels of transgene expression between the $\alpha$ GSU-LHX3a, $\alpha$ GSU-LHX3b, and $\alpha G S U-M 2-L H X 3$ lines were observed (Fig. 2F-H). Interestingly, these assays also indicated that the distribution of the $\alpha G S U$ $L H X 3 a$ and $\alpha G S U-L H X 3 b$ gene products in the anterior pituitary was somewhat more restricted to the ventral side of the gland than the M2-LHX3 transgene-produced protein (Fig. 2F-H). At higher magnification, it could be seen that in most $\alpha$ GSUstaining cells from $\alpha$ GSU-M2-LHX3 mouse pituitaries, there was nuclear staining of coexpressed $\mathrm{LHX} 3$ transgene product

(Fig. 2L). However, in $\alpha$ GSU-LHX3a (Fig. 2J) and $\alpha$ GSU-LHX3b (Fig. 2K) pituitaries, there were some $\alpha \mathrm{GSU}$-positive cells that appeared to lack expression of the transgene.

\section{Pituitary gonadotrope and hormonal changes associated with LHX3 isoform overexpression}

To assess the effect of LHX3 overexpression during pituitary development, the anterior lobe hormone-secreting cell populations of transgenic and wild-type mice were compared at $\mathrm{PI}$. In both sexes, overexpression of $\mathrm{LHX} 3 \mathrm{a}$ and $\mathrm{LHX} 3 \mathrm{~b}$ was found to reduce the number of cells staining for $\mathrm{LH}$, suggesting that the presence of the transgene product had decreased the number of differentiated pituitary gonadotropes (Fig. 3). The distribution and hormone expression levels of other pituitary cell types including thyrotropes, somatotropes, lactotropes, and corticotropes also were examined; however, no significant changes were observed between wild-type and transgenic animals (Fig. 3). Real-time PCR experiments also found reduced levels of $L H \beta$ and $F S H \beta$ mRNAs but not TSH $\beta$ mRNA (data not shown). To confirm the immunohistological results which indicated a reduction of gonadotropes in the $\alpha G S U-L H X 3 a$ overexpressing mice, serum LH, FSH, testosterone, and estrogen were measured. Alpha GSU-LHX3a male mice had a $\sim 50 \%$ reduction in circulating $\mathrm{LH}$ and $\mathrm{FSH}$ concentrations (Fig. 4A,B). Although there was variability in the measured levels (such that differences were not statistically different with $P>0.01$ ), the $\alpha G S U-L H X 3 a$ transgenic male mice had a trend of lower levels of testosterone than littermate non-transgenic 


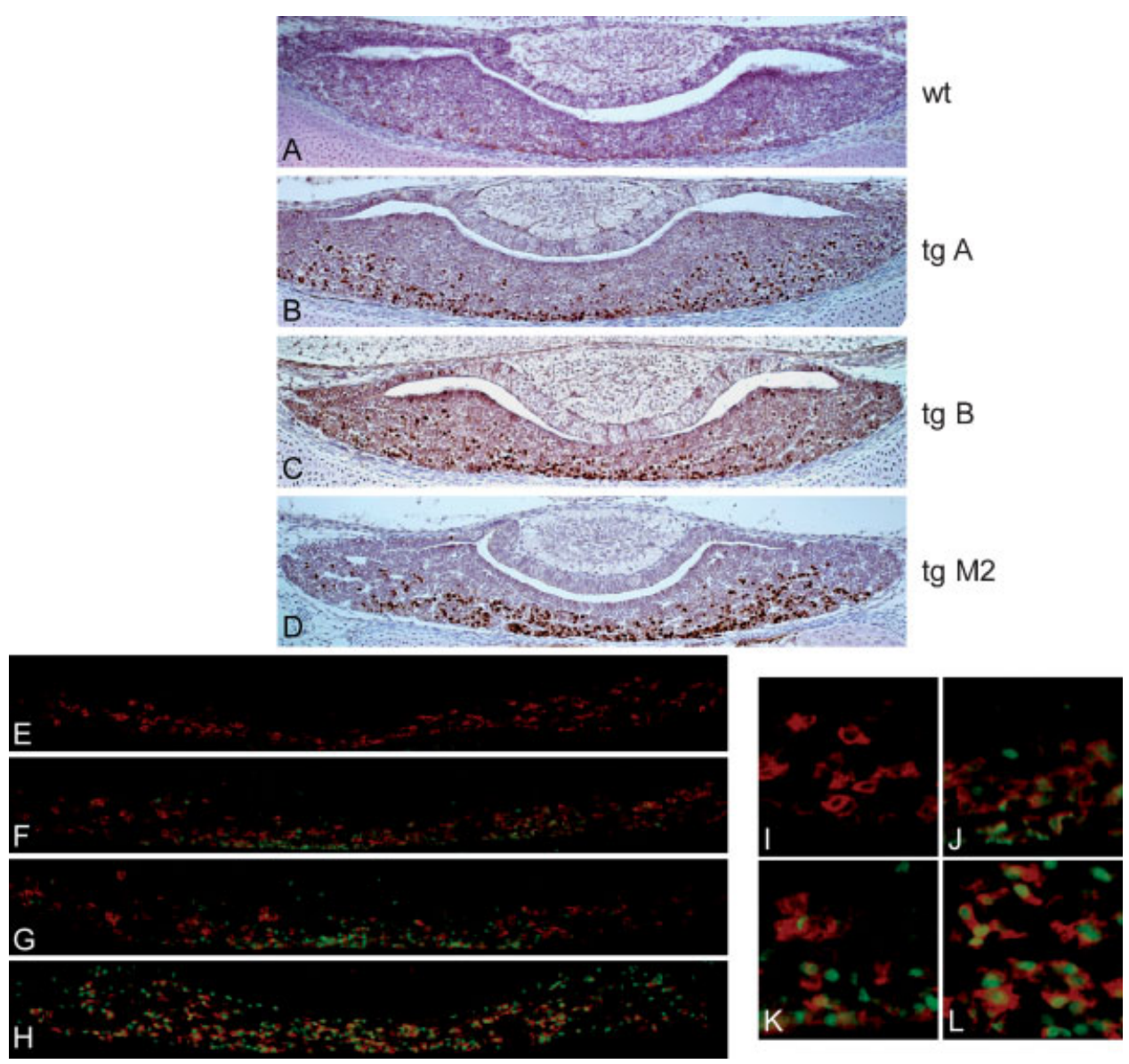

Fig. 2. $\alpha$ GSU-LHX3 transgene expression in the pituitary gland. A-D: Coronal pituitary sections from newborn (PI) wild-type (WT, part A), $\alpha G S U-L H X 3 a(\operatorname{tg}$ A, part B), $\alpha$ GSU-LHX3b (tg B, part C), and $\alpha$ GSU-M2-LHX3 (tg M2, part D) mice were immunostained for transgene product using an antibody against the Myc-epitope tag and detection using DAB chromogenic reactions. E-L: Double-labelled immunofluorescent assays of pituitary transgene expression in wild type (part E,I), $\alpha$ GSU-LHX3a (part F,J), $\alpha$ GSU-LHX3b (part G,K), and $\alpha G S U-M 2-L H X 3$ (part H,L) mice. Fluorescein-labelled anti-Myc antibodies were used to detect transgenic LHX3 protein and Texas Red conjugated antibodies were used to demarcate $\alpha \mathrm{GSU}$ hormone subunit expression.

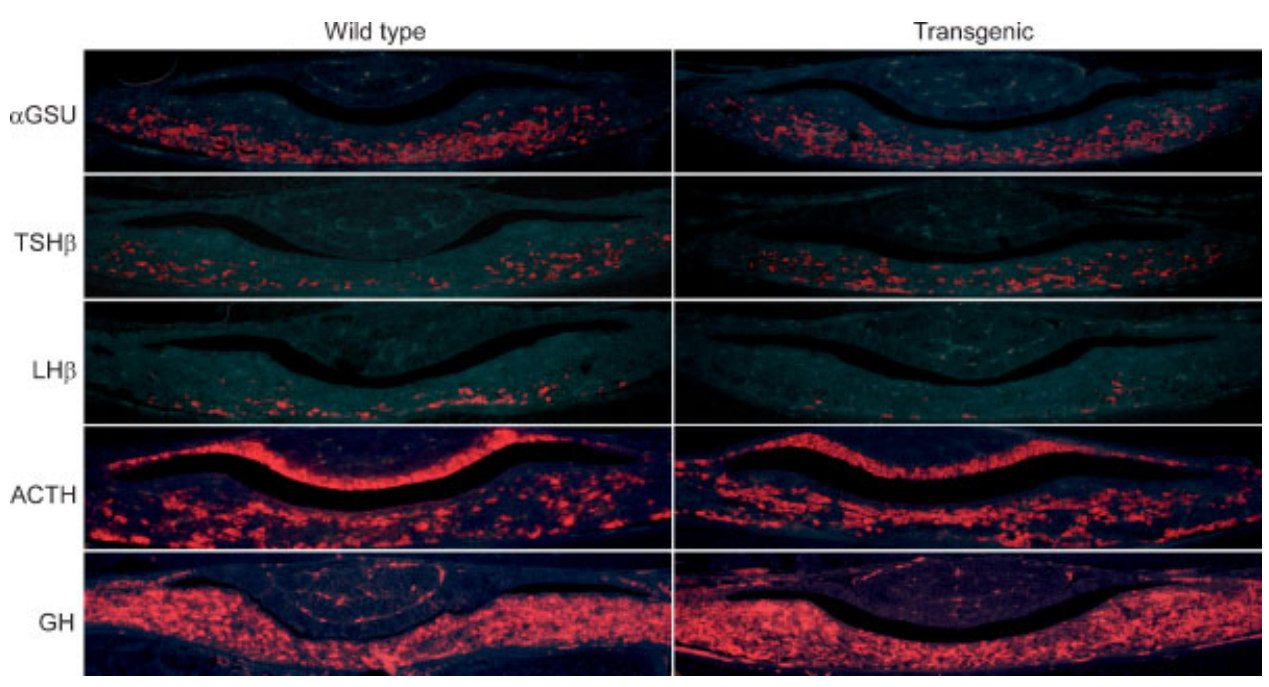

Fig. 3. Overexpression of LHX3a decreases the number of anterior pituitary gonadotropes. Wild-type and $\alpha G S U-L H X 3 a(P I)$ coronal pituitary sections were immunostained using antibodies directed against pituitary hormones: $\alpha$ GSU, TSH $\beta$, LH $\beta$, ACTH, and GH. Similar observations were made in animals of both sexes. 

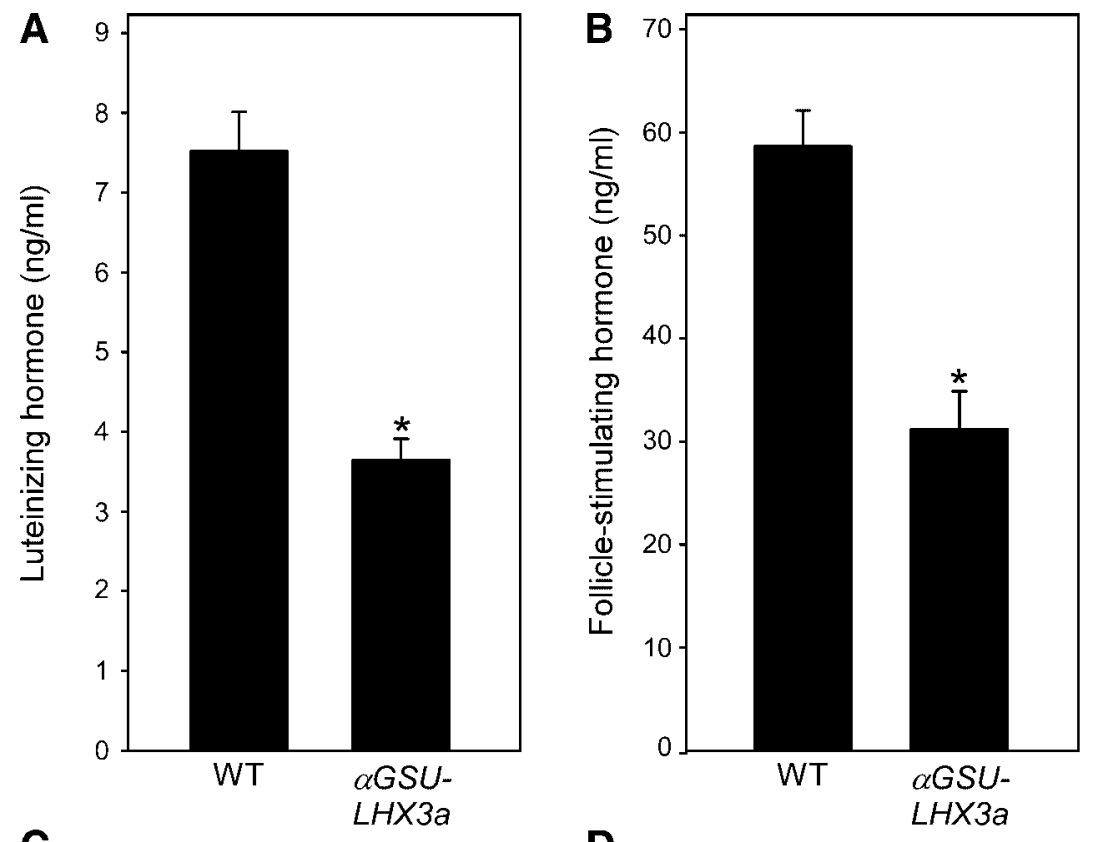

C

D
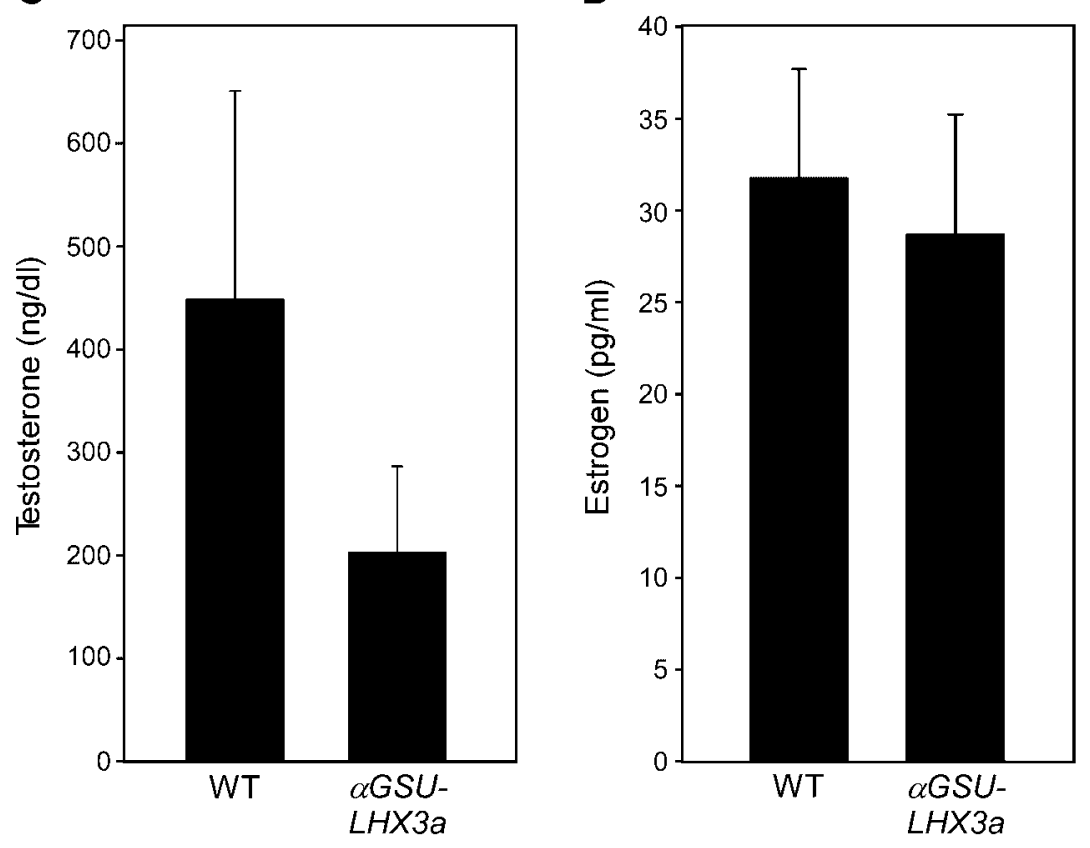

Fig. 4. Circulating reproductive hormone levels in $\alpha$ GSU-LHX3 transgenic male mice. Wild-type (n=8) and $\alpha G S U-L H X 3 a(n=8)$ male mice ( 12 weeks) were assayed for circulating concentrations of LH (part A), FSH (part B), testosterone (part C), and estrogen (part D). Serum levels of LH were measured by sandwich immunoradiometric assay. All other hormones were quantified using radioimmunoassays. $\mathbf{W T}=$ wild type. ${ }^{*} \boldsymbol{P}<\mathbf{0 . 0 0 I}$ versus control.

controls (Fig. 4C). Estrogen production was in the normal range (Fig. 4D). In this study, we concentrated on the males but serum hormone concentrations measured in the $\alpha$ GSU-LHX3a female mice indicated trends for reductions in $\mathrm{LH}$ and estrogen but these values were not in the statistically different range (data not shown).

$L H X 3 a$ and $L H X 3 b$ overexpression affects fertility and leads to a sex-specific reduction in viability

Fertility analyses were conducted by mating $\alpha$ GSU-nLacZ, $\alpha$ GSULHX3a, $\alpha$ GSU-LHX3b, and $\alpha$ GSU-M2-LHX3 mice with wild-type animals (Table I). The percentage of breeding pairs successfully generating offspring (productive matings), average number of litters produced, and mean litter sizes were recorded over a 4month mating period in order to calculate the relative fecundity (R.F.) of the specific pedigrees. Alpha GSU-nLacZ and $\alpha$ GSU-M2LHX3 mice had similar fertilities to non-transgenic mice (Table I, and data not shown). However, all $\alpha$ GSU-LHX3 $a$ and $\alpha G S U-L H X 3 b$ male mice analyzed in these reproductive studies were found to be infertile (Table I); therefore, these pedigrees were maintained through breeding of transgenic females. Subsequent generations of male mice produced through the breeding of $\alpha G S U-L H X 3 a$ and $\alpha G S U$-LHX3b females were also 
TABLE I. Reproductive performance of $\alpha$ GSU-LacZ, $\alpha$ GSU-LHX3a, $\alpha$ GSU-LHX3b, and $\alpha G S U-M 2-L H X 3$ mice

\begin{tabular}{|c|c|c|c|c|c|}
\hline Genotype-specific matings & $\mathrm{n}$ & Productive matings $\%^{\mathrm{a}}$ & Average litters ${ }^{\mathrm{b}}$ & Average litter size & Relative fecundity ${ }^{c}$ \\
\hline$\alpha G S U$-LacZ male $\times$ wt female & II & 91 & $3.6 \pm 0.4$ & $7.6 \pm 0.3$ & 25 \\
\hline$\alpha G S U-L H X 3 a$ male $\times$ wt female & 13 & 0 & 0 & 0 & 0 \\
\hline$\alpha$ GSU-LHX $3 a$ female $\times$ wt male & 45 & 82 & $2.4 \pm 0.3$ & $6.9 \pm 0.2$ & 14 \\
\hline$\alpha G S U-L H X 3 b$ male $\times$ wt female & 11 & 0 & 0 & 0 & 0 \\
\hline$\alpha G S U-L H X 3 b$ female $\times$ wt male & 30 & 90 & $2.9 \pm 0.3$ & $5.5 \pm 0.2$ & 14 \\
\hline$\alpha G S U-M 2-L H X 3$ male $\times$ wt female & 15 & 87 & $3.3 \pm 0.4$ & $8.1 \pm 0.3$ & 23 \\
\hline
\end{tabular}

${ }^{\mathrm{a}}$ Number of mice able to produce at least one litter/total number of animals bred. All mice were maintained as breeding partners for a minimum of 4 months or until extended cessation of productive mating (greater than 2 months).

${ }^{2}$ Average number of litters produced from breeding pairs housed together over a 4-month mating period.

'Relative fecundity is calculated as the following product: (productive matings) $\times$ (litter size) $\times($ number of litters).

shown to be infertile, indicating that this phenomenon was not founder-specific. The infertile $\alpha$ GSU-LHX $3 a$ and $\alpha$ GSU-LHX $3 b$ male mice have normal size testes and produce sperm with apparently normal morphology and motility (data not shown). Furthermore, these mice demonstrate copulatory behavior, but fail to form vaginal sperm plugs when placed with wild-type breeding partners.

Reproductive characteristics of females of the $\alpha G S U-n L a c Z$ $($ R.F. $=25)$ and $\alpha$ GSU-M2-LHX3 (R.F. = 23) pedigrees appeared to be unaffected by transgene expression, and these mice demonstrated similar relative fecundities to non-transgenic mice (Table I). However, reproduction of the $\alpha G S U-L H X 3 a$ $($ R.F. $=14)$ and $\alpha$ GSU-LHX3b (R.F. = I4) female mice was affected by transgene expression in comparison to controls (Table I). The data generated from the fertility studies alone did not account for the low numbers of transgenic offspring generated by breeding $\alpha$ GSU-LHX3 $a$ and $\alpha$ GSU-LHX3b females. Therefore, the efficacy of transgene propagation was measured within each of the transgenic mouse lines (Table 2). As expected, approximately one-half of $\alpha$ GSU-nLacZ offspring were confirmed to be transgenic at weaning (Table 2). Similar observations were made for $\alpha$ GSU-M2-LHX3 females (Table 2). By contrast, $\sim 45 \%$ (male plus female) of $\alpha G S U-L H X 3 a$ and only $\sim 18 \%$ of $\alpha$ GSU-LHX3b progeny were determined to be transgenic. In the $\alpha$ GSU-LHX3a line, the percentage of transgenic male progeny $(\sim 42 \%)$ appeared to be the major source of the overall reduction in total transgenic yield, whereas in the $\alpha G S U-L H X 3 b$ pedigree both sexes maintained significant reductions in transgenic offspring percentage (Table 2). These data suggest that there are two factors contributing to the low numbers of transgenic offspring from the breeding of $\alpha$ GSU-LHX3a and $\alpha$ GSU-LHX3b female mice. First, the females are reproductively compromised with low R.F. Secondly, it appears that embryonic and postnatal lethality reduce the number of transgenic offspring from matings of the $\alpha G S U-L H X 3 a$ and $\alpha G S U-L H X 3 b$ pedigrees: examination of sacrificed pregnant transgenic mothers reveals some resorbing transgenic embryos and some pups die postnatally before weaning (data not shown).

In addition to the reproductive consequences associated with the pituitary overexpression of $\mathrm{LHX} 3 \mathrm{a}$ and $\mathrm{LH} X 3 \mathrm{~b}$, most of the male mice generated from the $\alpha$ GSU-LHX $3 a$ and $\alpha$ GSU-LHX $3 b$ pedigrees die prematurely as young adults (Fig. 5). During the generation of the transgenic lines, it was noted that many of the $\alpha G S U-L H X 3 a$ and $\alpha$ GSU-LHX3b male founders died; RT-PCR testing revealed that only transgene-positive male founders who did not express the transgene had survived (data not shown). Female $\alpha$ GSU-LHX3 $a$ and $\alpha G S U-L H X 3 b$ founder mice, who continued to spawn male offspring exhibiting the lethal phenotype, were therefore used to generate animals for subsequent analyses. By II and 9 weeks of age, respectively, approximately $50 \%$ of the $\alpha$ GSU-LHX3a and $\alpha$ GSU-LHX3b transgenic males died (Fig. 5). Few $\alpha$ GSU-LHX3a male mice survived past 22 weeks of age. No transgene-associated reductions in viability have been observed within the male $\alpha$ GSU-nLacZ or $\alpha$ GSU-M2-LHX3 pedigrees (Fig. 5). Similarly, adult $\alpha G S U-L H X 3 a$ and $\alpha G S U-L H X 3 b$ transgenic females do not appear to be compromised in longevity compared to controls (data not shown). The $\alpha G S U-L H X 3 a$ and $\alpha G S U-L H X 3 b$ mouse male infertility and early death, and the reduction in female fertility made the generation of mice for subsequent analyses very challenging.

\section{$\alpha$ GSU-LHX3a and $\alpha$ GSU-LHX3b male urogenital tract pathology}

Post-pubertal male $\alpha$ GSU-LHX3 $a$ and $\alpha$ GSU-LHX3b transgenic mice die suddenly, occasionally exhibiting symptoms such as lethargy, increased respiration, dehydration, exophthalmos, and rough hair coats I-2 days prior to death. Dissection of terminal $\alpha$ GSU-LHX3a and $\alpha$ GSU-LHX3b transgenic males revealed a variety of gross lesions, including a markedly distended urinary bladder, moderate bilateral hydronephrosis, brick red discoloration of the pelvic urethra, and swelling of the corpus cavernosum bulbi that lead to midline caudal separation of the bulbocavernosis muscles (Fig. 6; and data not shown). These phenotypic characteristics are all compatible with urinary tract obstruction. Additionally, hemorrhage was often observed within the urinary bladder and the seminal vesicles. No structural changes in the urogenital tract or other tissues involved in the obstructive uropathy were observed before the animals were noticeably sick. Magnetic resonance imaging (MRI) of wild-type and terminally affected $\alpha$ GSU-LHX3a male mice was performed to determine if a urinary tract obstruction existed (Fig. 6C-F). Sagittal MRI revealed radiolucency in the penile urethra of the transgenic mice that appeared to physically

TABLE 2. Sex-specific efficiency of transgene propagation within the $\alpha G S U$-LacZ, $\alpha G S U-L H X 3 a, \alpha G S U-L H X 3 b$, and $\alpha G S U-M 2-L H X 3$ pedigrees

\begin{tabular}{|c|c|c|c|c|c|}
\hline Genotype-specific matings & $\mathrm{n}$ & Males/litter total & Females/litter total & $\%$ TG males & $\%$ TG females \\
\hline$\alpha$ GSU-LacZ male $\times$ wt female & 11 & $4.0 \pm 0.3$ & $3.6 \pm 0.3$ & 52.6 & 52.7 \\
\hline$\alpha G S U-L H X 3 a$ male $\times$ wt female & 13 & 0 & 0 & 0 & 0 \\
\hline$\alpha G S U-L H X 3 a$ female $\times$ wt male & 45 & $3.6 \pm 0.2$ & $3.3 \pm 0.2$ & 42.1 & 49.6 \\
\hline$\alpha G S U-L H X 3 b$ male $\times$ wt female & II & 0 & 0 & 0 & 0 \\
\hline$\alpha G S U-L H X 3 b$ female $\times$ wt male & 30 & $2.9 \pm 0.2$ & $2.6 \pm 0.2$ & 20.1 & 15.3 \\
\hline$\alpha G S U-M 2-L H X 3$ male $\times$ wt female & 15 & $4.1 \pm 0.3$ & $4.0 \pm 0.3$ & 51.7 & 52.4 \\
\hline
\end{tabular}

Transgenic status was confirmed at weaning. 


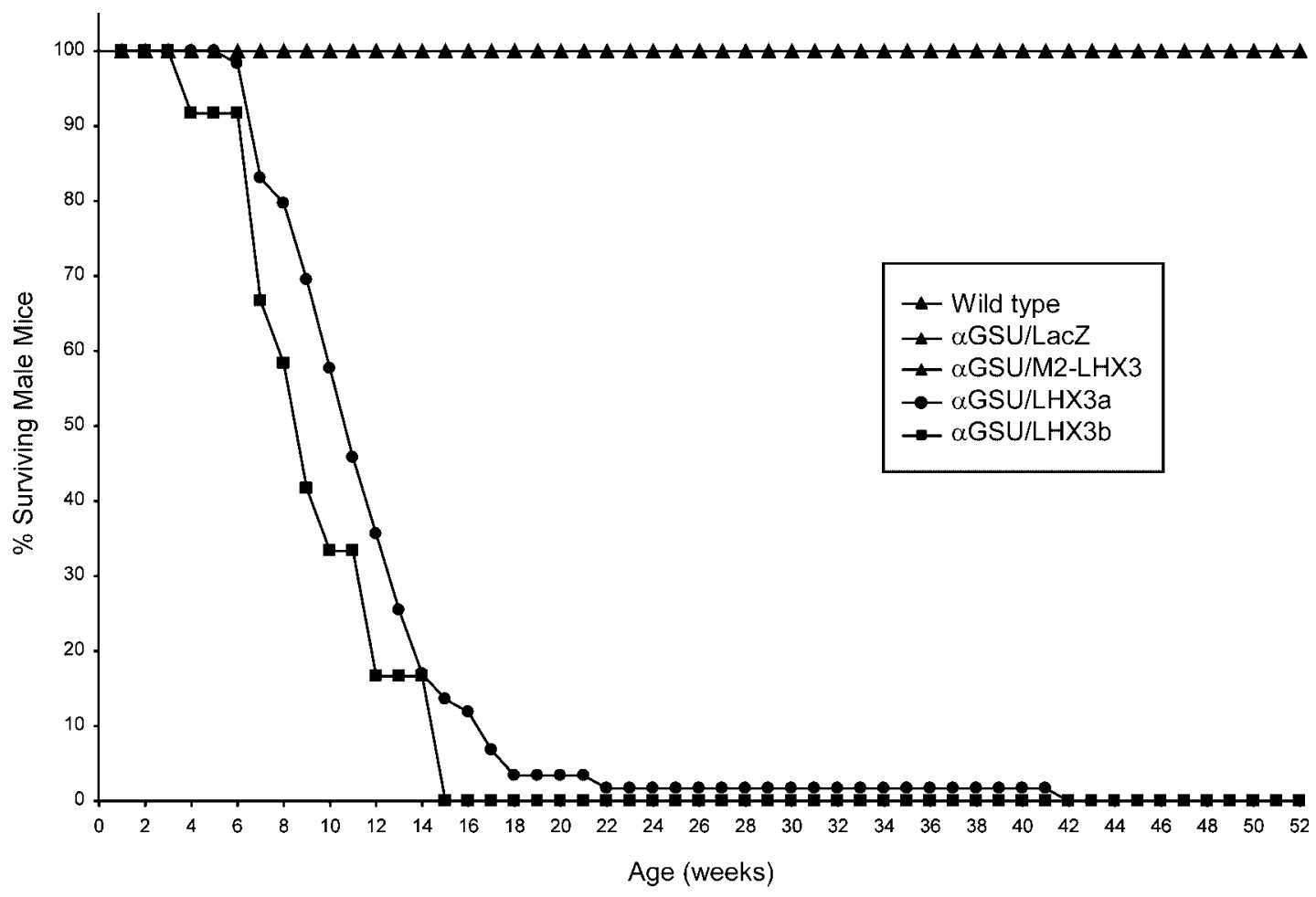

Fig. 5. Transgene-specific lethality. Survival curves for wild-type, $\alpha$ GSU-LacZ transgenic, and $\alpha G S U-L H X 3$ isoform transgenic male mice. Wild-type, $\alpha$ GSU-nLacZ, $\alpha$ GSU-LHX3a, $\alpha$ GSU-LHX3b, and $\alpha G S U-M 2-L H X 3$ males (including affected animals that had to be euthanized) were counted weekly for I year. Numbers of mice: wild-type $n=42 ; \alpha G S U-n L a c Z n=20 ; \alpha G S U-L H X 3 a n=59 ; \alpha G S U-L H X 3 b n=12$; $\alpha G S U-M 2-L H X 3 \mathrm{n}=34$.

impede urine outflow and to cause significant dilation of the corpus cavernosum bulbi, pelvic urethra, and urinary bladder (Fig. 6D). The urogenital tracts of wild-type, $\alpha$ GSU-LHX3a, and $\alpha G S U-L H X 3 b$ transgenic males were examined histologically in an effort to determine the nature of the material obstructing the penile urethra. Copulatory plug material consisting of eosinophilic coagulum containing entrapped spermatozoa was found to dilate and fill the penile urethrae and often the pelvic urethrae of terminally ill $\alpha$ GSU-LHX3a and $\alpha$ GSU-LHX3b transgenic mice (Fig. 6G,H, and data not shown). Copulatory plugs of lesser magnitude were also evident in the urethrae of $\alpha G S U-L H X 3 a$ and $\alpha G S U-L H X 3 b$ transgenic mice $(n=16 / 17)$ who had not yet displayed acute symptoms of urinary obstruction. By contrast, only a small amount of copulatory plug material was observed within the pelvic urethra of a single wild-type animal $(n=1 / 9)$.

The urethral sinus is a bulblike expansion or diverticulum of the membranous urethra located proximal to the bulb of the penis. This diverticulum is lined by urethral epithelium, extensive cavernous tissue (corpus cavernosum bulbi) containing urethral glands, and inner and outer smooth muscle layers, known as the bulbocavernosis muscles (Fig. 7A). In terminally affected transgenic mice, the corpus cavernosum bulbi was markedly congested and hemorrhagic (Fig. 7B). Furthermore, the urethral glands, which are numerous in the proximal portion of the urethral sinus, exhibited multifocal to diffuse necrosis (Fig. 7B). The congestion and hemorrhage extended along the submucosal cavernous tissue of the pelvic urethra as did the necrosis of the urethral glands (data not shown). In both the urethral sinus and pelvic urethra of $L H X 3 a$ and $L H X 3 b$ transgenic animals, necrosis and associated suppurative inflammation, hemorrhage, and edema was observed to often extend into the surrounding musculature (data not shown). The copulatory material found to occupy and distend the urethral lumen of transgenic mice contained infiltrating neutrophils and resulted in severe urethritis of adjacent epithelium, supporting the hypothesis that plug formation was not a post-mortem event (Fig. 7C,D).

Many histological changes, secondary to the urethral obstruction, were documented in the $\alpha$ GSU-LHX3 $a$ and $\alpha$ GSU$\mathrm{LHX} 3 \mathrm{~b}$ male mice. There was chronic fibrosis of the vesicular gland (Fig. 7E,F). Kidneys from terminally affected mice were enlarged and exhibited mild to severe tubular dilation by flocculent proteinaceous material (Fig. 8A,B, and data not shown). The transitional epithelium of the distended bladders was single layered, had a ruffled apical surface, and was finely vacuolated compared to controls (Fig. 8C,D). Other lesions documented in the $\alpha$ GSU-LHX3a and $\alpha$ GSU-LHX3b mice included mild interstitial inflammation of the prostate gland and retrograde sperm accumulation in the lumina of the prostate gland (Fig. 8E,F, and data not shown). The reproductive organs of $\alpha$ GSU-LHX3 $a$ and $\alpha G S U-L H X 3 b$ female mice were histologically unremarkable (data not shown).

The observed urogenital tract lesions in $\alpha$ GSU-LHX3a and $\alpha G S U-L H X 3 b$ transgenic males suggested that cause of death was severe uremia. To test this hypothesis, BUN levels were measured in both wild-type and $\alpha$ GSU-LHX3a transgenic adult mice (Fig. 8G). As expected, averages for the wild-type mice $(\sim 3 \mathrm{l} \mathrm{mg} / \mathrm{dl})$ fell within the normal BUN range. However, the $\alpha$ GSU-LHX3a mice exhibited greater than ninefold higher BUN levels (286 mg/dl; Fig. 8G). These findings support the hypothesis that $\alpha$ GSU-LHX $3 a$ and $\alpha G S U$ $\mathrm{LHX} 3 \mathrm{~b}$ male mice die from uremia resulting from obstructive uropathy. 

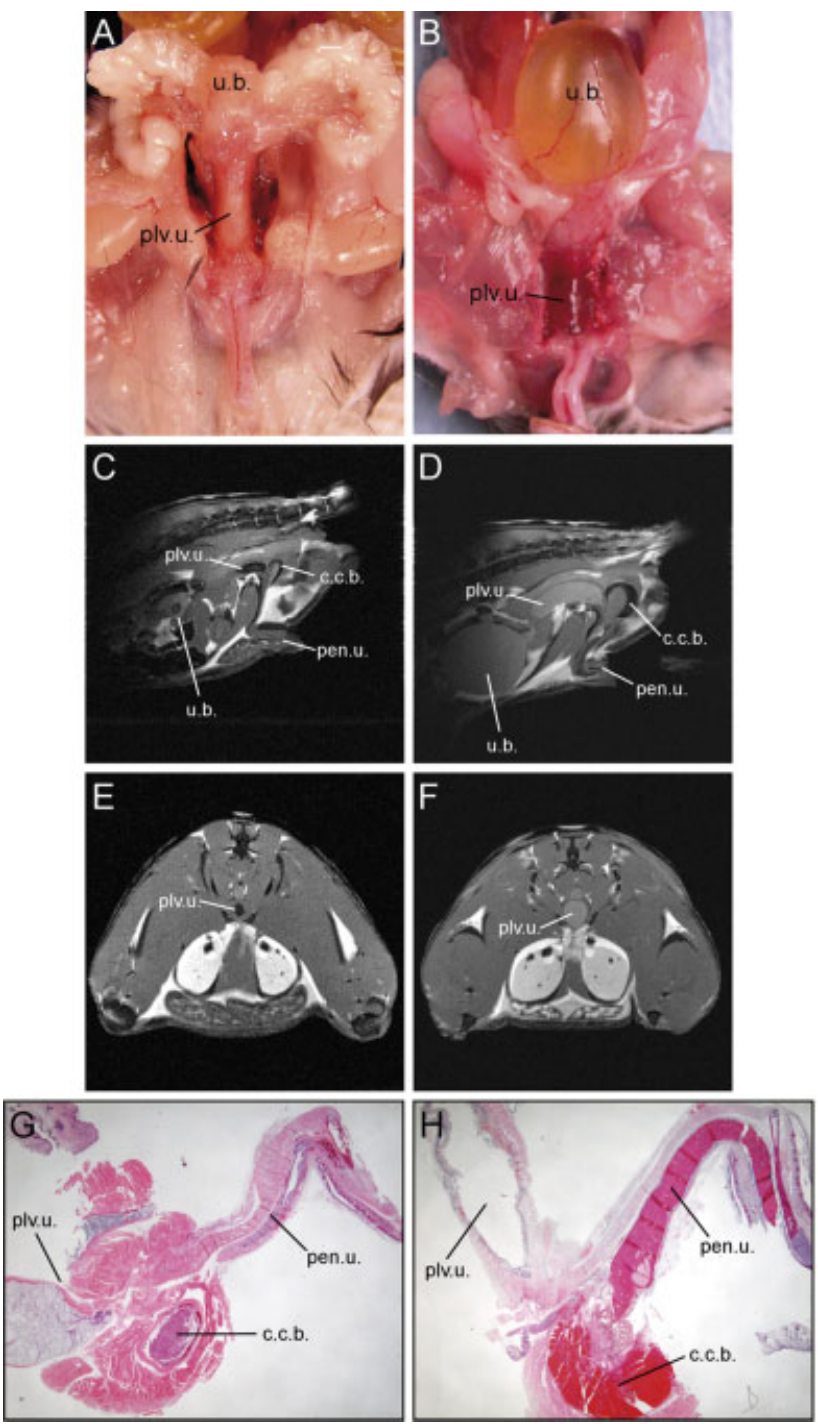

Fig. 6. $\alpha G S U-L H X 3 a$ and $\alpha G S U-L H X 3 b$ transgenic male mice develop gross abnormalities of the urogenital tract. A,B: Photographs of wild-type (part A) and $\alpha$ GSU-LHX3b (part B) urogenital tracts. The $\alpha$ GSU-LHX3b transgenic mouse displays a markedly distended urinary bladder (u.b.) and a hemorrhagic pelvic urethra (plv.u.) in comparison to the wild-type control. C-F: Magnetic resonance imaging (MRI) of wild-type and $\alpha$ GSU-LHX3a urogenital tracts. Sagittal (parts C,D) and transverse (parts E,F) MRI of wild-type (parts C,E) and $\alpha$ GSU-LHX3a (parts D,F) male urogenital tracts. The urinary bladder (u.b.), pelvic urethra (plv.u.), and corpus cavernosum bulbi (c.c.b.) of the $\alpha$ GSU-LHX3a mouse are markedly distended in comparison to wild-type control. The $\alpha G S U$-LHX3a sagittal image (part D) exhibits radiolucency in the penile urethra that appears to physically impede urine outflow resulting in the observed urogenital tract distention. G,H: Copulatory plug material obstructs the penile urethrae of $\alpha G S U-L H X 3 a$ and $\alpha G S U-L H X 3 b$ transgenic mice. Photomicrographs of hematoxylin and eosin-stained tissue sections of the urethral tracts of wild-type (part G) and $\alpha$ GSU-LHX3b (part H) transgenic male mice. Eosinophilic copulatory plug material fills and dilates the urethra of the $\alpha G S U$-LHX3b mouse. Significant hemorrhage and congestion of the cavernous tissue is also apparent in the representative transgenic animal. c.c.b. $=$ corpus cavernosum bulbi; plv.u. = pelvic urethra; pen.u. = penile urethra. [Color figure can be viewed in the online issue, which is available at www.interscience.wiley.com.]
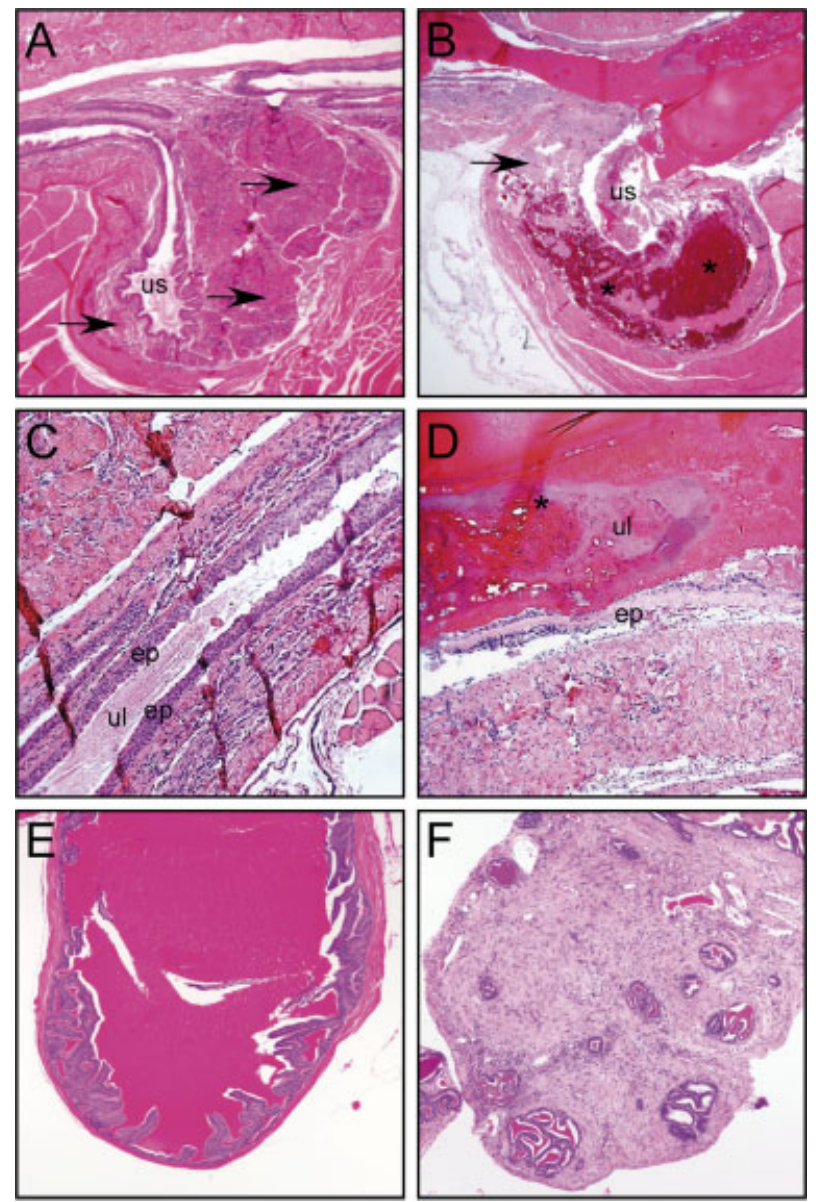

Fig. 7. Reproductive tissue disease in $\alpha G S U-L H X 3 a$ and $\alpha G S U-L H X 3 b$ transgenic mice. A,B: Photomicrographs of a hematoxylin and eosin stain of the cavernous tissue of the urethral sinus (us) of a $\alpha G S U-L H X 3 b$ transgenic male mouse (part B) compared to a wild-type animal (part A). The $\alpha G S U-L H X 3 b$ transgenic mouse (part B) displays hemorrhage and congestion of the cavernous tissue $(*)$ and diffuse necrosis of the urethral glands (arrow). Part A shows the urethral sinus of a wild-type mouse with no congestion or hemorrhage and normal urethral gland morphology (arrows $=$ urethral glands). C,D. $\alpha$ GSU-LHX3a and $\alpha$ GSU-LHX3b transgenic male mice retain urethral plugs that alter urethral morphology. Photomicrographs of hematoxylin and eosin-stained sections. Wild-type (part C) and $\alpha$ GSU-LHX3a (part D) pelvic urethrae. D: Proteinaceous copulatory material fills the urethral lumen (ul) of the $\alpha$ GSU-LHX3a pelvic urethra $\left.{ }^{*}\right)$ and detached transitional epithelial cells (ep) can be seen on the surface of the plug. E,F: $\alpha G S U-L H X 3 a$ and $\alpha G S U-L H X 3 b$ transgenic mice develop abnormal vesicular glands as a result of obstructive uropathy. Photomicrographs of hematoxylin and eosin-stained vesicular gland sections harvested from wild-type (part E) and $\alpha G S U-L H X 3 b$ (part F) male mice. The $\alpha$ GSU-LHX3b animal exhibited severe chronic fibrosis of the vesicular tissue, likely due to chronic inflammation. [Color figure can be viewed in the online issue, which is available at www.interscience.wiley.com.]

\section{Discussion}

Loss of function studies have confirmed the necessity of the LHX3 gene for development of the pituitary gland (Sheng et al., 1996; Netchine et al., 2000; Bhangoo et al., 2006). To examine the consequences of $\mathrm{LHX} 3$ protein overexpression, the $\alpha G S U$ promoter was used to drive overexpression of individual cDNAs encoding LHX3a, LHX3b, and M2-LHX3 in the developing pituitary. The pituitary glands of the $\alpha G S U-L H X 3 a$ 

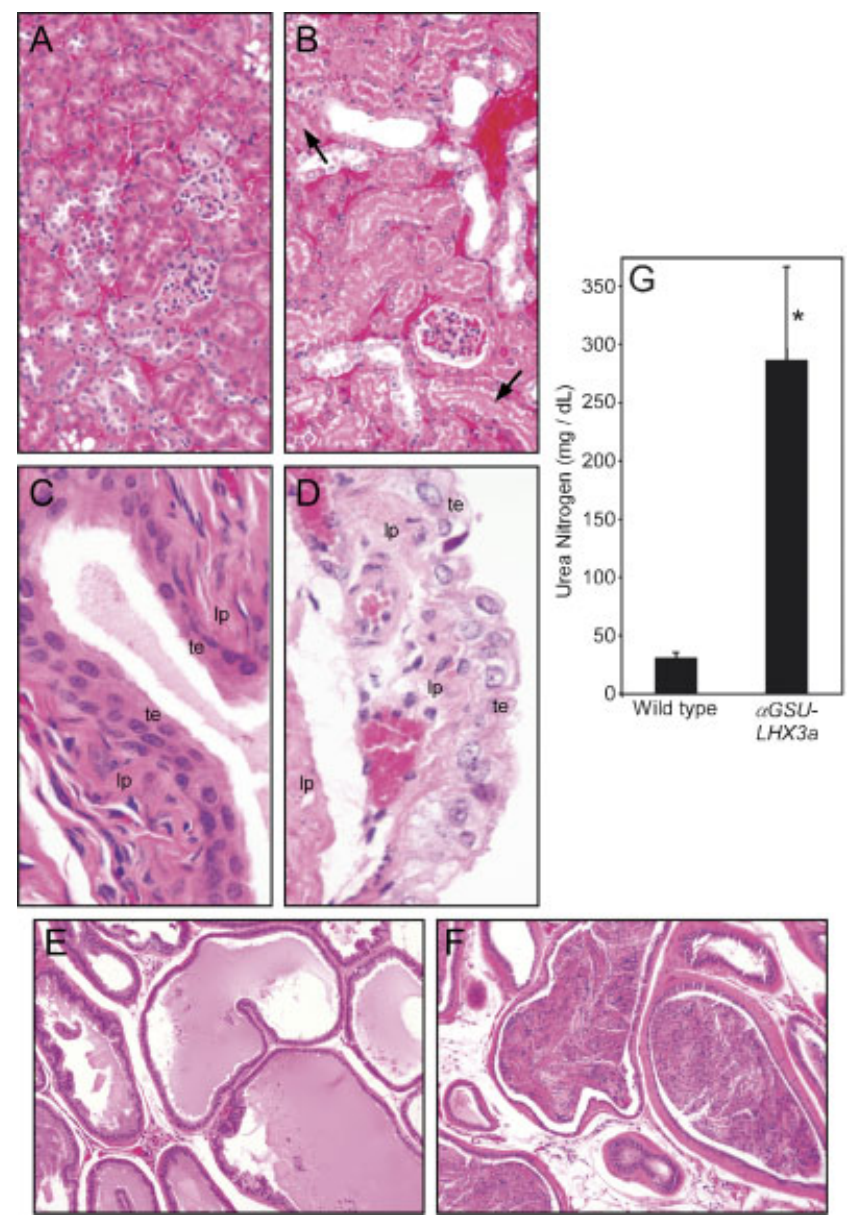

Fig. 8. Tissue damage and uremia in $\alpha G S U-L H X 3 a$ and $\alpha G S U-L H X 3 b$ transgenic mice. A,B: $\alpha G S U-L H X 3 a$ and $\alpha G S U-L H X 3 b$ animals develop hydronephrosis resulting from obstructive uropathy. Photomicrographs of wild-type (part A) and $\alpha$ GSU-LHX3a (part B) of hematoxylin and eosin-stained kidney sections. In the $\alpha G S U-L H X 3 a$ transgenic mouse, there is moderate tubular dilation and accumulation of flocculent proteinaceous material (arrows). C,D:Dysmorphology of the urinary bladder epithelium is observed in $\alpha G S U-L H X 3 a$ and $\alpha G S U-L H X 3 b$ transgenic mice as a result of urinary tract blockage. Photomicrographs of hematoxylin and eosin-stained urinary bladder epithelium sections isolated from wild-type (part C) and representative $\alpha$ GSU-LHX3b (part D) male mice. The transitional epithelium (t.e.) of the $\alpha G S U$-LHX $3 b$ mouse is single layered, has a ruffled apical surface, and is finely vacuolated. Ip = lamina propria. E,F: $\alpha$ GSU-LHX3a and $\alpha$ GSU-LHX3b transgenic mice develop abnormal prostate glands as a result of obstructive uropathy. Photomicrographs of hematoxylin and eosin-stained wild-type (part E) and $\alpha$ GSU-LHX3a (part F) prostatic tissue. Retrograde sperm and associated inflammation is present in the lumen of the transgenic animal (part F). G: Obstructive uropathy and early death in the $\alpha G S U-L H X 3$ mice is associated with uremia. Blood urea nitrogen (BUN) analysis of wild-type $(n=6)$ and $\alpha G S U$-LHX3a transgenic mice $(n=6)$. The average concentration of BUN was within the normal range for wild-type mice (18-31 mg/dl). However, the $\alpha$ GSU-LHX3a transgenic animals exhibited BUN levels ninefold above this range. ${ }^{*} \boldsymbol{P}<0.001$ versus control. [Color figure can be viewed in the online issue, which is available at www.interscience.wiley.com.]

and $\alpha$ GSU-LHX3b mice have fewer numbers of gonadotrope cells compared to controls and low circulating gonadotropin hormone levels. The male $\alpha$ GSU-LHX3a and $\alpha$ GSU-LHX3b transgenic mice are infertile due to obstructive uropathy and die of secondary consequences of this disease, including kidney dysfunction and uremia. The female $\alpha$ GSU-LHX3a and $\alpha$ GSU$L H X 3 b$ transgenic mice are viable but have reduced fertility. Transgenic mice expressing the M2-LHX3 isoform or the beta galactosidase enzyme are apparently normal.

Comparatively, the $\alpha$ GSU-M2-LHX3 animals (which have no obvious phenotype) maintain a transgene expression level significantly higher than either the $\alpha$ GSU-LHX3a or $\alpha$ GSU$\mathrm{LHX} 3 \mathrm{~b}$ pedigrees. It is interesting to note that, in all tested cases, female mice expressed the transgene at lower levels than their male counterparts. Real-time PCR experiments evaluating the endogenous $\alpha$ GSU gene demonstrated that males have a higher level of expression than females; it therefore appears that the transgene promoter operates in a similar fashion. The observed sex-specific differences in transgene expression levels may contribute to the sex-related differences in fertility and viability observed in LHX3a or LHX3b transgenic animals. It was somewhat surprising to find that overexpression of LHX3a or LHX3b elicited loss of gonadotrope cells. LHX3 expression has been associated with the proliferation and differentiation of many anterior lobe cell types, including the $\alpha$ GSU-expressing gonadotropes and thyrotropes. Therefore, predictions of the consequences of LHX3 isoform overexpression might have included phenotypes such as pituitary hyperplasia and/or increased hormone production. The similar disease displayed by the $\alpha$ GSU-LHX3 $a$ and $\alpha$ GSU$\mathrm{LHX} 3 \mathrm{~b}$ male mice is an intriguing result. Previous experiments have shown that $\mathrm{LHX} 3 \mathrm{a}$ has greater DNA binding and gene regulatory capacities than $\mathrm{LHX} 3 \mathrm{~b}$ on the limited number of suggested target genes for LHX3 (Sloop et al., 1999, 200 la; Bridwell et al., 200I; Yaden et al., 2005), but overexpression of both factors yielded a similar outcome in this study. In fact, the phenotype of the $\alpha$ GSU-LHX3b mice may be more severe; these mice die at a somewhat faster rate (Fig. 5).

It is also important to consider that using the $\alpha$ GSU promoter to target LHX3 protein to the pituitary gland should disturb the usual dorsal/ventral gradient of Lhx3 expression. During development in mice, LHX3 is more abundant dorsally and ISL I more abundant ventrally (Ericson et al., 1998; Raetzman et al., 2002). Studies of the early growth factor signals that prime the expression gradients of transcription factor such as $\mathrm{LHX} 3$ across the developing pituitary indicated that the gradients are critical for the differentiation of pituitary cell types, especially the thyrotrope cells (Ericson et al., 1998; Treier et al., 1998, 200I). A ventral expression of LHX3 guided by the $\alpha$ GSU promoter might therefore be predicted to result in a major shift in proportions of cell types. However, this is not observed in the $\alpha G S U-L H X 3 a / b$ mice described here, in which only a partial loss of gonadotropes is seen. Other cell types, including the thyrotropes, appear unaffected. It may be that the gonadotropes are especially sensitive to LHX3 levels during pituitary development.

The observed phenotype of the $\alpha$ GSU-LHX3a or $\alpha$ GSU-LHX3b pedigrees suggests that there is an upper threshold sensitivity of the mouse anterior pituitary to $\mathrm{LHX} 3$ transcription factor levels. By contrast, the lack of one $L H X 3$ allele in heterozygous mice and humans does not appear to affect pituitary function (Sheng et al., 1996; Netchine et al., 2000; Bhangoo et al., 2006). The inappropriate activation of regulatory genes can sometimes elicit physiological responses as deleterious as the ablation of the gene functions. Recent studies have illustrated sensitivity to transcription factor dosage. For example, whereas Pitx $2^{\text {neo/neo }}$ homozygotes (a hypomorphic allele) fail to differentiate gonadotropes and have a reduction of thyrotropes and somatotropes, $\alpha$ GSU-Pitx 2 transgenic mice display an increased number of gonadotropes (Suh et al., 2002; Charles et al., 2005). Several hypotheses can explain the actions of $\mathrm{LHX} 3 \mathrm{a} / \mathrm{b}$ overexpression shown in this study. These include the mechanism that the $\mathrm{LHX} 3 \mathrm{a}$ and $\mathrm{LHX} 3 \mathrm{~b}$ proteins promote determination or differentiation events associated with 
gonadotrope development too early during pituitary organogenesis, and as a result, many gonadotropes are lost. This would suggest that LHX3a and LHX3b have similar roles during gonadotrope specification and that many of the true target genes for these factors remain uncharacterized. Indeed, both of the mRNAs encoding these proteins are found in rodent cell lines that represent stages of gonadotrope development (Sloop et al., 200 la; West et al., 2004). Recently, a side population enriched in progenitor cells has been characterized in the anterior pituitary (Chen et al., 2005). A majority of these cells produced stem cell antigen I and were found to coexpress LHX4, whereas differentiated cells were shown to downregulate LHX4 and to upregulate LHX3. In the transgenic mice described in this study, the overexpression of LHX3 driven by the $\alpha$ GSU promoter throughout the developing anterior lobe may lead to premature differentiation of gonadotropes from some stem cells, thus reducing the pool of progenitor cells required for their normal expansion.

An alternate explanation is that the excess LHX3a and LHX3b proteins may interfere with normal gonadotrope development in a dominant negative manner. Both LHX3a and LHX3b proteins have the LIM domains that mediate interactions with many suggested cofactors of LIM-HD protein function (Bach, 2000; Hunter and Rhodes, 2005). Consistent with this model, the M2-LHX3 isoform lacks this region and the $\alpha$ GSU-M2-LHX3 mice do not develop the disease.

The lack of an overt phenotype in the $\alpha$ GSU-M2-LHX3 mice (despite a high level of transgene expression) suggests that the gonadotrope and thyrotrope cell types are not sensitive to increased levels of this protein. This may indicate that M2-LHX3 does not play a significant role in vivo or that M2-LHX3 is important in other environments, such as in other pituitary cell types or in the nervous system. It has been speculated that M2LHX3 might play a dominant negative role in some circumstances (Sloop et al., $200 \mathrm{la}$ ) but, to date, in vitro experiments do not support this idea (JJS, KWS, SJR, unpublished results). The observations made in this study also suggest that a dominant negative role is unlikely, at least in $\alpha G S U$-expressing cells. A recent study has identified a human patient with pituitary disease and likely nervous system defects associated with a mutation that causes a frame-shift prior to the $M 2$ codon in the $L H X 3 a$ transcript (Bhangoo et al., 2006). It is probable that $L H X 3$ mRNAs are subject to nonsense-mediated decay in this patient (Bhangoo et al., 2006) However, if that is not the case, then only the M2-LHX3 protein could perhaps be translated in such a patient. If so, this would be evidence that M2-LHX3 protein is alone insufficient for the roles of LHX3 in normal pituitary and nervous system development. Overall, these data indicate that the amino terminus and LIM domains of LHX3 are important in functions in the pituitary.

It has been hypothesized that male obstructive uropathy syndrome can result from hormonal dysregulation (Sokoloff and Barile, 1962). This syndrome is characterized by the presence of a copulatory plug blocking the flow of urine from the urinary bladder, pelvic urethra, and/or penile urethra (Maronpot et al., 1999). The condition differs from the protein plugs that are occasionally present in the urethrae of euthanized mice, due to the coincidence of lesions such as dilated bladder, hydronephrosis, and inflammation of the urinary tract and adjacent tissues (Maronpot et al., 1999). The reproductive hormone imbalances in the $\alpha$ GSU-LHX $3 a$ and $\alpha$ GSU-LHX3b mice may therefore be the cause of the observed syndrome. Indeed, urogenital pathologies have been observed in other mouse models exhibiting hypothalamus-pituitary-gonad (HPG) axis hormonal imbalances. The EL mouse is a model for multifactorial idiopathic epilepsy (Todorova et al., 2003). In addition to seizures, male EL mice experience a high frequency of sudden death resulting from abnormal ejaculation and obstructive uropathy at sexual maturity (Todorova et al., 2003).
It has been hypothesized that seizure activity occurring in the limbic structures of EL mice may affect the HPG axis and result in obstructive urogenital syndrome (Todorova et al., 2003). $\alpha$ GSU-PTTG (pituitary tumor-transforming gene) transgenic male mice died prematurely as a result of urinary tract obstruction and display elevated levels of $\mathrm{LH}$ and testosterone (Abbud et al., 2005). However, the authors of this work attribute the sudden death of these animals to testosterone induced prostatic hyperplasia with renal tract inflammation (Abbud et al., 2005). Urethral obstructions associated with decreases in testosterone have also been described. Transgenic male mice expressing human P450 aromatase have elevated estradiol levels combined with reduced testosterone levels ( $\mathrm{Li}$ et al., 2003). P450 aromatase catalyzes the final steps in ovarian $E_{2}$ biosynthesis and can utilize testosterone as a substrate for this process ( $\mathrm{Li}$ et al., 2003). The P450 aromatase transgenic mice displayed higher maximal bladder pressure and decreased urinary flow rate in comparison to controls, which the authors attributed to functional, rather than physical, urethral obstruction resulting from smooth muscle atrophy ( $\mathrm{Li}$ et al., 2003). Overall, we favor a model in which imbalances in the pituitary and gonadal sex hormone levels in the mice is associated with the onset of the conditions that lead to the obstructive uropathy. We cannot exclude other mechanisms such as a transient expression of the transgene in the embryo causing developmental defects in the developing urogenital tract; however, we have not observed any expression of the transgene protein in embryonic or adult urogenital tract tissue (SCC, JJS, RDM, and SJR, unpublished observations).

We hypothesize that death of the $\alpha$ GSU-LHX3a and $\alpha$ GSU$L H X 3 b$ male mice results from uremia due to obstructive uropathy. Male mice normally discharge viscous spermcontaining fluid, even without participation in copulatory behavior. The incomplete emission of copulatory fluid in transgenics produces a solidified plug in the distal end of the urethra, resulting in significant dilation of the urogenital tract. Normal cavernous tissue smooth muscle function is requisite for rodent and human penile erection (Mizusawa et al., 200I). The $\alpha G S U-L H X 3 a$ and $\alpha G S U-L H X 3 b$ transgenic mice display profound structural abnormalities of the corpus cavernosum tissue and surrounding musculature. Mice with excised bulbocavernosis and levator ani muscles are severely impaired in their ability to impregnate females, presumably due to reduced capacity for erection and suboptimal deposition of copulatory fluid (Sachs, 1982). The amount of copulatory fluid adhering to the glans penis of mice with excised bulbocavernosis and levator ani muscles was nearly four times greater than that of control males (Sachs, 1982), reminiscent of the incomplete emission of seminal fluid observed within the $\alpha G S U-L H X 3 a$ and $\alpha$ GSU-LHX3b pedigrees. Testosterone has been shown to be important for many aspects of corpus cavernosum development and function in mouse. The etiology of the obstructive uropathy documented in the $\alpha$ GSU-LHX $3 a$ and $\alpha G S U-L H X 3 b$ pedigrees is likely complex. However, it does appear that the reduction of gonadotropins and apparent subsequent decrease in testosterone concentration observed in the transgenic mice is likely to be a causative factor in the obstructive uropathy. The $\alpha$ GSU-LHX3a and $\alpha$ GSU-LHX3b male transgenic mice highlight anterior pituitary sensitivity to regulatory protein abundance and represent an interesting model to study endocrine influence on male reproductive disease.

\section{Acknowledgments}

We are grateful to Drs. Teri Belecky-Adams, Dring Crowell, Lisa Cushman, Marin Garcia III, Paul Herring, Judy Hallett, Stephen Konieczny, Richard Maurer, Pamela Mellon, A. F. Parlow, and members of the Camper and RADIL labs for 
reagents and advice. We thank Chad Hunter for comments on the manuscript. This study was supported by grants to SJR from the National Institutes of Health (NIH HD42024) and the National Science Foundation (IBN 0I3 I702); to SAC from the $\mathrm{NIH}$ (HD34283); and to CLF from the NIH (K26 RR0 I 88I I ). JJS was an Elizabeth Steele Creveling Memorial Scholar during this work. The University of Virginia Center for Research in Reproduction Ligand Assay and Analysis Core is supported by NICHD (SCCPRR) grant U54-HD28934.

\section{Literature Cited}

Abbud RA, Takumi I, Barker EM, Ren SG, Chen DY, Wawrowsky K, Melmed S. 2005. Early multipotential pituitary focal hyperplasia in the alpha-subunit of glycoprotein hormone-driven pituitary tumor-transforming gene transgenic mice. Mol Endocrinol 19:1383-1391.

Bach I. 2000. The LIM domain: Regulation by association. Mech Dev 91:5-17.

Bach I, Rhodes SI, Pearse RV, II, Heinzel T, Gloss B, Scully KM, Sawchenko PE, Rosenfeld MG. 1995. P-Lim, a LIM homeodomain factor, is expressed during pituitary organ and cell commitment and synergizes with Pit-I. Proc Natl Acad Sci USA 92:2720 2724.

Bhangoo AP, Hunter CS, Savage JJ, Anhalt H, Pavlakis S, Walvoord EC, Ten S, Rhodes SJ. 2006 Clinical case seminar: A novel LHX3 mutation presenting as combined pituitary hormona deficiency. J Clin Endocrinol Metab 91:747-753.

Bridwell JA, Price JR, Parker GE, McCutchan Schiller A, Sloop KW, Rhodes SJ. 200I. Role of the LIM domains in DNA recognition by the Lhx3 neuroendocrine transcription factor. Gene 277:239-250.

Charles MA, Suh H, Hjalt TA, Drouin J, Camper SA, Gage PJ. 2005. PITX genes are required for cell survival and Lhx3 activation. Mol Endocrinol 19:1893-1903.

Chen J, Hersmus N, Van Duppen V, Caesens P, Denef C, Vankelecom H. 2005. The adult pituitary contains a cell population displaying stem/progenitor cell and early-embryonic characteristics. Endocrinology 146:3985-3998.

Ericson J, Norlin S, Jessell TM, Edlund T. 1998. Integrated FGF and BMP signaling controls the progression of progenitor cell differentiation and the emergence of pattern in the embryonic anterior pituitary. Development 125:1005-1015.

Granger A, Bleux C, Kottler ML, Rhodes SJ, Counis R, Laverriere JN. 2006. The LIMhomeodomain proteins IsI-I and Lhx3 act with steroidogenic factor I to enhance gonadotrope-specific activity of the gonadotropin-releasing hormone receptor gene promoter. Mol Endocrinol 20:2093-2108.

Hobert O, Westphal H. 2000. Functions of LIM-homeobox genes. Trends Genet 16:75-83.

Hunter CS, Rhodes SJ. 2005. LIM-homeodomain genes in mammalian development and human disease. Mol Biol Rep 32:67-77.

Keegan CE, Camper SA. 2003. Mouse knockout solves endocrine puzzle and promotes new pituitary lineage model. Genes Dev 17:677-682.

Kendall SK, Gordon DF, Birkmeier TS, Petrey D, Sarapura VD, O'Shea KS, Wood WM, Lloyd RV, Ridgway EC, Camper SA. 1994. Enhancer-mediated high level expression of mouse pituitary glycoprotein hormone alpha-subunit transgene in thyrotropes, gonadotropes, and developing pituitary gland. Mol Endocrinol 8:1420-1433.

Li X, Makela S, Streng T, Santti R, Poutanen M. 2003. Phenotype characteristics of transgenic male mice expressing human aromatase under ubiquitin $C$ promoter. I Steroid Biochem Mol Biol 86:469-476.

Maronpot RR, Boorman GA, Gaul BW. 1999. Pathology of the mouse: Reference and atlas. Vienna, IL: Cache River Press. xi, 699 p.

McGillivray SM, Bailey JS, Ramezani R, Kirkwood BJ, Mellon PL. 2005. Mouse GnRH receptor gene expression is mediated by the LHX3 homeodomain protein. Endocrinology 146:2180-2185.

Mizusawa H, Hedlund P, Hakansson A, Alm P, Andersson KE. 200I. Morphological and functional in vitro and in vivo characterization of the mouse corpus cavernosum. Br J Pharmacol I32:1333-1341.
Netchine I, Sobrier ML, Krude H, Schnabel D, Maghnie M, Marcos E, Duriez B, Cacheux V Moers A, Goossens M, Gruters A, Amselem S. 2000. Mutations in LHX3 result in a new syndrome revealed by combined pituitary hormone deficiency. Nat Genet 25:182-186.

Pincas H, Amoyel K, Counis R, Laverriere JN. 200I. Proximal cis-acting elements, including steroidogenic factor I, mediate the efficiency of a distal enhancer in the promoter of the rat gonadotropin-releasing hormone receptor gene. Mol Endocrino 15:319-337.

Raetzman LT, Ward R, Camper SA. 2002. Lhx4 and Propl are required for cell survival and expansion of the pituitary primordia. Development 129:4229-4239.

Roberson MS, Schoderbek WE, Tremml G, Maurer RA. 1994. Activation of the glycoprotein hormone alpha-subunit promoter by a LIM-homeodomain transcription factor. Mol Cell Biol 14:2985-2993.

Sachs BD. 1982. Role of striated penile muscles in penile reflexes, copulation, and induction of pregnancy in the rat. J Reprod Fertil 66:433-443.

Savage JJ, Yaden BC, Kiratipranon P, Rhodes SJ. 2003. Transcriptional control during mammalian anterior pituitary development. Gene 319:I-19.

Seidah NG, Barale JC, Marcinkiewicz M, Mattei MG, Day R, Chretien M. 1994. The mouse homeoprotein mLIM-3 is expressed early in cells derived from the neuroepithelium and persists in adult pituitary. DNA Cell Biol 13:1163-1180

Sharma K, Sheng HZ, Lettieri K, Li H, Karavanov A, Potter S, Westphal H, Pfaff SL. I 998. LIM homeodomain factors Lhx3 and Lhx4 assign subtype identities for motor neurons. Cell 95:817-828.

Sheng HZ, Zhadanov AB, Mosinger B, Jr., Fujii T, Bertuzzi S, Grinberg A, Lee EJ, Huang SP, Mahon KA, Westphal H. 1996. Specification of pituitary cell lineages by the LIM homeobox gene Lhx3. Science 272:1004-1007.

Sheng HZ, Moriyama K, Yamashita T, Li H, Potter SS, Mahon KA, Westphal H. 1997. Multistep control of pituitary organogenesis. Science 278:1809-1812

Sloop KW, Meier BC, Bridwell JL, Parker GE, Schiller AM, Rhodes SJ. 1999. Differential activation of pituitary hormone genes by human Lhx3 isoforms with distinct DNA binding properties. Mol Endocrinol 13:2212-2225.

Sloop KW, Showalter AD, Von Kap-Herr C, Pettenati MJ, Rhodes SJ. 2000. Analysis of the human LHX3 neuroendocrine transcription factor gene and mapping to the subtelomeric region of chromosome 9 . Gene 245:237-243.

Sloop KW, Dwyer C], Rhodes SJ. 200 la. An isoform-specific inhibitory domain regulates the LHX3 LIM homeodomain factor holoprotein and the production of a functional alternate translation form. J Biol Chem 276:3631I-36319.

Sloop KW, Parker GE, Hanna KR, Wright HA, Rhodes SJ. 200 Ib. LHX3 transcription factor mutations associated with combined pituitary hormone deficiency impair the activation of pituitary target genes. Gene 265:6I-69.

Sokoloff L, Barile MF. 1962. Obstructive genitourinary disease in male STR/IN mice. Am J Pathol 4I:233-246.

Suh H, Gage PJ, Drouin J, Camper SA. 2002. Pit 2 is required at multiple stages of pituitary organogenesis: Pituitary primordium formation and cell specification. Development 129:329-337.

Todorova MT, Dangler CA, Drage MG, Sheppard BJ, Fox JG, Seyfried TN. 2003. Sexual dysfunction and sudden death in epileptic male EL mice: Inheritance and prevention with the ketogenic diet. Epilepsia 44:25-31.

Treier M, Gleiberman AS, O'Connell SM, Szeto DP, McMahon JA, McMahon AP, Rosenfeld MG. 1998. Multistep signaling requirements for pituitary organogenesis in vivo. Genes Dev 12:1691-1704.

Treier M, O'Connell S, Gleiberman A, Price J, Szeto DP, Burgess R, Chuang PT, McMahon AP, Rosenfeld MG. 200I. Hedgehog signaling is required for pituitary gland development Development 128:377-386.

West BE, Parker GE, Savage J], Kiratipranon P, Toomey KS, Beach LR, Colvin SC, Sloop KW, Rhodes S. 2004. Regulation of the follicle-stimulating hormone beta gene by the LHX3 LIM-homeodomain transcription factor. Endocrinology 145:48664879.

Yaden BC, Savage JJ, Hunter CS, Rhodes SJ. 2005. DNA recognition properties of the LHX3b LIM homeodomain transcription factor. Mol Biol Rep 32:I-6.

Yaden BC, Garcia M, III, Smith TP, Rhodes SJ. 2006. Two promoters mediate transcription from the human LHX3 gene: Involvement of nuclear factor I and specificity protein I. Endocrinology 147:324-337.

Zhadanov AB, Bertuzzi S, Taira M, Dawid IB, Westphal H. 1995. Expression pattern of the murine LIM class homeobox gene Lhx3 in subsets of neural and neuroendocrine tissues. Dev Dyn 202:354-364.

Zhu X, Rosenfeld MG. 2004. Transcriptional control of precursor proliferation in the early phases of pituitary development. Curr Opin Genet Dev 14:567-574. 